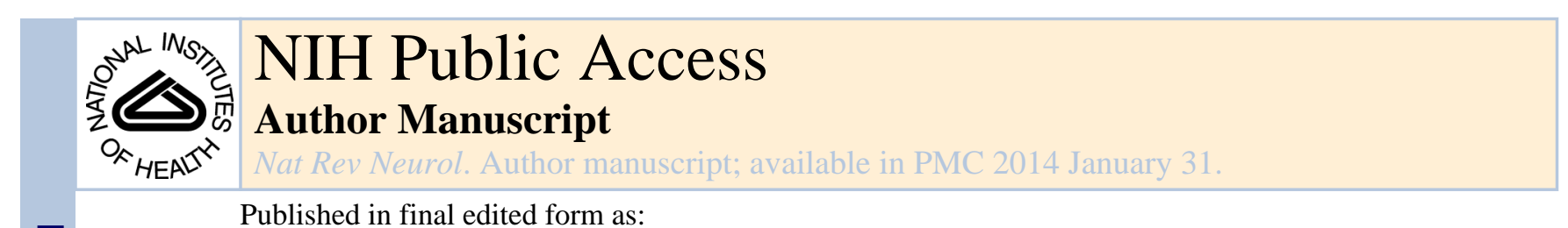

Published in final edited form as:

Nat Rev Neurol. 2013 May ; 9(5): 277-291. doi:10.1038/nrneurol.2013.56.

\title{
Progress in gene therapy for neurological disorders
}

\author{
Michele Simonato, \\ Section of Pharmacology, Department of Medical Sciences, University of Ferrara, Fossato di \\ Mortara 17-19, 44121 Ferrara, Italy.
}

Jean Bennett,

University of Pennsylvania, USA

Nicholas M. Boulis,

Emory University, USA

Maria G. Castro,

University of Michigan, USA

David J. Fink,

University of Michigan, USA

William F. Goins,

University of Pittsburgh, USA

Steven J. Gray,

University of North Carolina, USA

Pedro R. Lowenstein,

University of Michigan, USA

Luk H. Vandenberghe,

Harvard Medical School, USA

Thomas J. Wilson,

University of Michigan, USA

John H. Wolfe, and

Research Institute of Children's Hospital of Philadelphia, USA

Joseph C. Glorioso

University of Pittsburgh, USA

(C) 2013 Macmillan Publishers Limited. All rights reserved

Correspondence to: M. Simonato michele.simonato@unife.it.

Competing interests

L. H. Vandenberghe declares associations with the following companies: GenSight Biologics, Novartis Institutes of Biomedical Research. J. Bennett declares an association with the following company: GenSight Biologics. N. M. Boulis declares an association with the following company: Ceregene. See the article online for full details of the relationships. L. H. Vandenberghe is an inventor on patent applications WO/2005/033321; WO/2007/127264 and WO/2009/136977. P. R. Lowenstein and M. G. Castro are inventors on European patent applications 1181376B1; 1786474B1 and granted US patent 7,858,590B2. J. H. Wolfe is an inventor on granted US patents 7,402,308; 5,958,767; 6,528,306; 6,541,255 and 6,680,198. J. C. Glorioso is an inventor on Australian patent applications 733945 and 2005302408; European patent application 904395; granted US patents 5,658,724; 5,879,934; 5,804,413; 6,261,552; $7,078,029 ; 5,849,571 ; 5,849,572 ; 7,531,167 ; 8,309,349$, and international patent application WO/07/922,839. The other authors declare no competing interests.

Author contributions

All authors researched the data for the article, and provided substantial contributions to discussions of the content and writing of the article. M. Simonato and G. C. Glorioso reviewed and edited the manuscript before submission.

Supplementary information is linked to the online version of the paper at www.nature.com/nrneurol 


\section{Abstract}

Diseases of the nervous system have devastating effects and are widely distributed among the population, being especially prevalent in the elderly. These diseases are often caused by inherited genetic mutations that result in abnormal nervous system development, neurodegeneration, or impaired neuronal function. Other causes of neurological diseases include genetic and epigenetic changes induced by environmental insults, injury, disease-related events or inflammatory processes. Standard medical and surgical practice has not proved effective in curing or treating these diseases, and appropriate pharmaceuticals do not exist or are insufficient to slow disease progression. Gene therapy is emerging as a powerful approach with potential to treat and even cure some of the most common diseases of the nervous system. Gene therapy for neurological diseases has been made possible through progress in understanding the underlying disease mechanisms, particularly those involving sensory neurons, and also by improvement of gene vector design, therapeutic gene selection, and methods of delivery. Progress in the field has renewed our optimism for gene therapy as a treatment modality that can be used by neurologists, ophthalmologists and neurosurgeons. In this Review, we describe the promising gene therapy strategies that have the potential to treat patients with neurological diseases and discuss prospects for future development of gene therapy.

\section{Introduction}

The nervous system is a complex and difficult organ system to study, and the brain is an organ where many of the most pervasive disease processes arise, for which the cause remains elusive. These diseases encompass a broad spectrum of pathological states and can have global or local effects on metabolism, and neural development and function. Drugs and neurosurgical procedures have generally not proven effective in the treatment of these disorders owing to the complexity and limited understanding of the pathophysiology involved. In addition, the blood-brain barrier (BBB) limits the use of systemic treatments as it impedes widespread delivery of therapeutic agents to the CNS.

Genetic interventions to supply gene products that permanently restore function and even induce replacement of lost cells could represent an alternative to standard pharmacological approaches. Such approaches, in which DNA or RNA is used as the pharmacological agent, are defined as gene therapy. Despite its tortuous development, the field of gene therapy has matured, emerging as a legitimate and promising choice for the treatment of many nervous system disorders. Improvements in gene transfer methods can largely be attributed to the development of sophisticated delivery vehicles that have been evaluated in animal models of human disease. On the basis of numerous preclinical studies, early clinical trials have been carried out to test the safety and, in some cases, efficacy of gene therapy. Some results have been encouraging, suggesting that this approach will soon be translated to the clinic.

In this Review, we describe some of the most promising emerging gene therapy approaches for the treatment of various nervous system disorders. We begin by describing the most common gene delivery systems and how vector design and biology fits their application. We discuss progress in the treatment of retinal degeneration, neuropathic pain and polyneuropathy in the PNS, and in the CNS we focus on lysosomal storage diseases, Parkinson disease (PD), epilepsy and glioblastoma. Progress has been made in the field of gene therapy to treat other disorders, but advances for the diseases described above are representative of the development of nervous system gene therapy. Our opinion is that gene therapy has the potential to prevent the onset or slow progression of neurological diseases and possibly to restore normal function. Our hope is that in the future, some of these gene therapy approaches will become available for patients. 


\section{Gene therapy vectors}

The success of gene therapy depends on effective gene delivery. Over the past two decades, vectors to deliver the therapeutic gene have undergone remarkable changes in design to meet the complex demands of transgene delivery to the host. Great effort has gone into the creation of nonviral gene delivery vehicles, including naked DNA or RNA, liposomes, and nanoparticles, owing to their low cost and ability to deliver a large cargo. Therapeutic gene expression with such vectors, however, is typically low and of limited duration. ${ }^{1}$ None of these nonviral vectors contain the highly evolved mechanisms that wild-type viruses use to insert their genetic material into host cells and to alter cell functions. The use of gene vectors to treat patients with nervous system disorders has a complex history that in part mirrors the history of vector development. The most common CNS gene therapy vector is an adenoassociated virus (AAV), but lentiviral vectors have an increasing role in CNS gene therapy, and have the advantage of a larger transgene capacity. Herpes simplex virus (HSV) and adenoviral vectors have also been used to treat CNS disorders, especially tumours.

\section{Viral vectors}

The key to development of an effective viral vector is to harness the virus biology for transgene expression rather than viral replication after host transduction. Achievement of this goal has not been easy and, indeed, suitable vectors are still in development and vary with respect to level and duration of transgene expression, cellular specificity and safety issues (Table 1).

Current design strategies for the most common viral vectors make use of the unique technical advantages of each vector (Figure 1). For example, vectors constructed from an AAV are safe, nonpathogenic and afford long-term gene expression. However, such vectors have limited transgene capacity, can be difficult to target to the appropriate location, require a high dose for effective gene expression, and are readily eliminated by humoral immune responses in patients previously exposed to the virus. ${ }^{2}$ Other vectors, such as lentiviruses and retroviruses, can insert novel genetic material into the host cell chromosome, which is essential to avoid therapeutic gene loss in dividing cells. However, oncogenesis resulting from chromosomal insertion of the vector DNA poses a potential problem with the use of these viral vectors. ${ }^{3}$

Vectors with a large transgene capacity include those constructed from adenoviruses and $\mathrm{HSV}$, which have the potential for effective gene targeting and sustained transgene expression. These vectors can, however, cause toxicity and inflammation stemming from 'leaky' expression of viral genes and reaction to the vector coat. Avoidance of these adverse effects requires complete vector genome silencing, which can affect transgene expression. These vectors can all be targeted by innate immune responses that, together with humoral immune responses, might trigger immune-mediated inflammatory processes that limit vector delivery, gene expression and the potential for redosing. ${ }^{4}$ Despite these limitations, many of these vectors have proven to be highly effective gene delivery tools if used in a careful manner that takes advantage of their natural biology and strengths.

\section{Vector targeting through capsid modifications}

Considerable advances in vector targeting have been made in terms of the overall efficiency of transduction, delivery to a wide target area, and in some cases delivery to a specific tissue or cell type. Improvements to AAV vectors over the past decade serve as a good example of how targeting can be improved. Alternative serotype capsids (the protein shell of a virus), rational mutagenesis of the capsid, insertion of targeting peptides into the capsid, and derivation of novel capsids by directed evolution have all been used to improve targeting of 
AAV vectors. Over 100 AAV capsid variants have been identified, each with a potentially different cell tropism that provides a broad toolkit of vectors for optimized transgene delivery. For example, AAV9 could be used for CNS applications owing to its ability to cross the BBB after intravenous injection. ${ }^{5-7}$ Enthusiasm for the use of AAV9 as a vector might be tempered by its high liver tropism (relative to its CNS tropism), but this tendency can be reduced by introduction of point mutations into the capsid, ${ }^{8}$ or via the introduction of micro-RNA target sequences that respond to microRNAs highly expressed in the liver, but not in the CNS, into viral genes or virally delivered transgenes to limit their expression in the liver, thereby reducing toxicity to nontarget areas. ${ }^{9}$

Peptide insertions can confer novel features to AAV capsids and, by using a phage display library to generate novel peptides, modified AAV2 capsids were developed that specifically targeted the cerebral vasculature after intravenous injection. ${ }^{10}$ To generate entirely new AAV capsids, DNA shuffling of capsid genes can be combined with directed evolution to select for novel traits. ${ }^{11}$ In one study, a novel AAV capsid was generated that, after intravenous injection, showed increased expression at sites of epilepsy damage, with almost no expression in liver, heart and muscle; that is, a favourable safety and bio-distribution profile. ${ }^{12}$ Similar to drug optimization, virus capsid engineering can increase vector potency and cell specificity and reduce the potential for adverse effects.

\section{Transgene expression control}

The level of transgene expression and cell-specific expression can be directed by cis-acting elements contained within the vector genome or by the innate tropism of the virus itself. For example, the choice of 5' untranslated region (UTR), 3' UTR, enhancer, promoter and polyadenylation signal can affect cell specificity and level of transgene expression. ${ }^{13-20}$ Through changes to the vector genome design, transgene expression can be modulated across at least a 1000-fold range and be restricted to specific cell populations.

\section{Gene therapy strategies}

A good example of progress toward gene therapy strategies is the work done in retinal diseases. At least six strategies for transgene delivery and expression have been explored, extending the use of gene therapy from autosomal recessive sensorineural diseases (Leber congenital amaurosis) to complex inherited and acquired diseases, such as age-related macular degeneration.

Gene augmentation and/or gene knockdown is aimed at correcting gene expression in the context of a loss-of-function mutation by introducing the wild-type cDNA, ${ }^{21}$ or at reducing expression of or eliminating a toxic gain-of-function gene product. ${ }^{22-24}$ Gene augmentation is often limited by a narrow therapeutic window owing to the progressive nature of the disease, whereby the therapeutic target cell often degenerates and dies.

Correction of the primary genetic lesion at the chromosomal level is another approach to gene therapy, but is challenging owing to limited efficiency of current gene-editing technologies. Delivery of a vector carrying a transgene that encodes a decoy protein to the target organ is a technique that has been used to treat pathological ocular neovascularization. This approach involved expression of the sFlt 1 transgene, which encodes a tyro sine kinase that binds vascular endothelial growth factor-a key driver of pathology in ocular neovascularization (Supplementary Table 1 online). ${ }^{25}$

Delivery of vectors to express genes that encode proteins with antineovascular or antiapoptotic function is also possible. For example, delivery of the pigment epitheliumderived factor-encoding gene, which has antiangiogenic properties that are not fully 
characterized is in development for treatment of choroidal neovascularization (Supplementary Table 1 online). Increased expression of genes encoding growth factors has been used to enhance nerve regeneration. Induction of a photoreceptor phenotype through expression of the CRX transcription factor has been shown in retinal stem cells. ${ }^{26}$ Such an approach has also been used to produce functional auditory hair cells in the cochlea in animal models. ${ }^{27,28}$ Finally, molecular prosthetics is an option to restore visual function by introducing light-sensitive ion channel proteins or ion pump proteins derived from bacteria and algae, such as the channel rhodopsin or halorhodopsin subfamilies, into the retina. ${ }^{29}$ This approach is unique in that it can theoretically restore some function by rendering remaining cells in the retina light-sensitive and harnessing the function of remaining circuitry in the retina or optic nerve long after the primary disease-causing cells have died. Ultimately, this kind of gene therapy might be useful for all in herited diseases or environmentally induced degenerative processes that affect retinal pigment epithelium and photoreceptors, and also for blindness due to untreated retinal detachment.

The approaches described above all require some intact CNS function or sufficient plasticity to incorporate the neural signal from the treated peripheral organs. Sufficient plasticity exists in at least some retinal degenerative diseases, as demonstrated in a functional MRI study in recipients of retinal pigment epilethium-specific $65 \mathrm{kDa}$ protein (RPE65) retinal gene augmentation therapy, in whom light-induced cortical responses were present even after long-term (>3.5 decades) visual deprivation. ${ }^{30}$

\section{Gene therapy targets \\ Sensory organs and the PNS}

Considerable progress has been made in developing gene therapy for sensorineural disorders, in particular blinding retinal degenerative diseases, for which no treatments are available. The mammalian eye has been the target organ in a number of therapeutic trials of gene therapy, because of its accessibility, its benign immunological response to gene transfer, and the availability of noninvasive functional and structural analyses. Many of these studies have focused on rare diseases, such as retinitis pigmentosa, Leber congenital amaurosis and choroideraemia, which could provide stepping stones to treat more-prevalent blinding conditions that have limited treatment options such as age-related macular degeneration, glaucoma and diabetic retinopathy.

Gene therapy to treat retinal blindness has progressed furthest of all the therapeutic strategies discussed above, with several completed or ongoing clinical trials (Supplementary Table 1 online). Three independent clinical trials have demonstrated safety and efficacy of RPE65 gene augmentation in patients with Leber congenital amaurosis. ${ }^{31-33}$ This strategy was aided by progress in identification and cloning of the disease-associated genes, and has provided momentum for several studies of gene therapy for other inherited forms of blindness (Supplementary Table 1 online). More than 25 genes associated with blindness have been recognized after identification of the first two- the choroideraemia and rhodopsin genes-in 1990. ${ }^{34-36}$ A number of the retinal disease-associated mutant genes can also cause hearing and/or vestibular disorders (Usher syndrome). Progress in the field of genetics has led to the development of animal models of blindness and an improved understanding of disease pathogenesis. Studies in these models have been used for proof of concept in gene therapy and have led to clinical trials.

Progress has been made in gene therapy for other, extraocular sensory deficits, albeit at a slower rate than for retinal applications. The clinical need here is large: hearing loss and deafness due to presbycusis is a growing problem owing to the ageing of populations. Although surgical access is more of a challenge for cochlear than for retinal disorders, proof 
of concept for gene therapy in several inherited conditions leading to deafness has been demonstrated. ${ }^{37,28}$ In one of these studies, cochlear hair cells were regenerated after noiseinduced degeneration, by delivering a transcription factor known to be important in the development of stereocilia. ${ }^{28}$ In another study, a gene encoding the missing vesicular glutamate transporter-3 was delivered to the cochlea in mice lacking this enzyme; gene augmentation therapy at least partially restored hearing in these mice. ${ }^{37} \mathrm{~A}$ third pivotal proof-of-concept study showed correction of a splicing defect in one form of Usher syndrome through administration of antisense oligonucleotides to a mouse model of the disease. ${ }^{38}$ Finally, although target organs such as the nose and tongue are more accessible than the retina and cochlea, very few studies have addressed disorders of smell and taste, ${ }^{39}$ probably owing to the complex aetiologies of these disorders and risk-benefit ratios for these indications.

\section{Pain and sensory neuropathy}

Nonreplicating HSV vectors are promising vehicles for delivery of therapeutic transgenes to the PNS. ${ }^{40}$ Enthusiasm for the use of this vector has been prompted by the high rate of infectivity of the virus in dorsal root and trigeminal ganglia, as well as its life-long persistence in sensory neurons in a nonintegrated state that is thought to mimic viral latency. HSV vector delivery to the PNS is achieved by simple inoculation of the skin. The vector enters nerve terminals and undergoes retrograde axonal transport to the nucleus, where the therapeutic gene is expressed in the absence of viral lytic functions (Figure 2). Potential applications for HSV vectors include the treatment of peripheral pain dis orders (inflammatory or neuropathic) ${ }^{41,42}$ and nerve degeneration (sensory polyneuropathy). ${ }^{43}$

In preclinical studies involving rodent models of pain, subcutaneous inoculation with a nonreplicating HSV vector expressing the opioid peptide enkephalin substantially reduced pain-related behaviour caused by inflammation, nerve damage or cancer. ${ }^{44,45} \mathrm{~A}$ similar vector expressing the glutamic acid decarboxylase $(G A D)$ transgene to cause release of the inhibitory neuro-transmitter $\gamma$-aminobutyric acid (GABA) prevented neuropathic pain caused by spinal nerve trauma or diabetes. ${ }^{46,47}$ In addition, HSV vectors that expressed antiinflammatory peptides, including IL-4 and IL-10, reduced pain in models of CNS and PNS neuropathic pain. ${ }^{48-50}$

Pain control has been achieved by using an HSV vector to express the glycine receptor-a ligand-gated $\mathrm{Cl}^{-}$channel that inhibits neurotransmission-in sensory neurons, combined with application of glycine to activate nerve silencing and provide a molecular switch for pain control. ${ }^{42}$ Similarly, subcutaneous inoculation of rodent models with nonreplicating HSV vectors that express conventional or atypical neurotrophic factors, including nerve growth factor, neurotrophin-3 and erythropoietin, has been shown to prevent progression of neuropathy caused by an overdose of pyridoxine, treatment with chemotherapeutic drugs, or diabetes. ${ }^{51-56}$

An HSV vector construct to express the prepro-enkephalin gene was the first to advance to clinical trials. ${ }^{57}$ In phase I-II of the trial, patients with intractable pain from cancer did not experience adverse events related to vector inoculation. Studies to treat painful diabeticneuropathy using a viral vector to express a $G A D$ transgene are planned. ${ }^{58}$

\section{Genetic diseases}

A large number of human genetic diseases affect the CNS; these conditions are frequently characterized by neurodegeneration and typically have pathology that is widely distributed in the brain. Transfer of the normal gene into diseased cells can correct the biochemical defect. Other gene transfer strategies besides direct gene replacement may be needed 
depending on the underlying nature of the disease; for example, neurotrophic factors may rescue diseased cells even when the gene defect is not known. Alternatively, small interfering RNA approaches may be used to suppress dominant-negative genes (for example, in Huntington disease) ${ }^{59}$ However, to deliver the therapeutic gene to the entire brain is a major challenge, especially in humans, whose brains are 2,000-3,000 times larger than a mouse brain. ${ }^{60}$ Potential routes of vector delivery for widespread distribution of the transgene, which have shown promise in animal models, include injections of the vector along multiple injection tracks; ${ }^{61}$ transport of the vector to brain regions distal to the injection site via neural pathways; ${ }^{62-64}$ intravenous injection so that the vector crosses the $\mathrm{BBB} ;{ }^{5,6}$ and injection of the vector into the cerebrospinal fluid spaces for distribution within the brain via the circulation (Figure 3). ${ }^{65,66}$

The properties of some proteins, such as lysosomal enzymes, can be harnessed to achieve wider distribution of the expressed protein and, therefore, provide a broader therapeutic effect. More than 50 human lysosomal storage diseases (LSDs) exist, most of which are characterized by accumulation of storage material in somatic and nervous system cells, leading to progressive degeneration of the CNS, usually beginning in early childhood. In the normal brain, lysosomal enzymes are released from the cell and taken up by neighbouring cells. Gene therapy for LSDs makes use of this mechanism to transfer lysosomal enzymes released from a set of genetically corrected cells and taken up into mutant cells, in a process known as cross-correction. ${ }^{67}$ Studies in animal models using transplantation of cells corrected for the genetic defect or direct viral vector gene transfer have shown that the levels of functional enzyme delivered are sufficient to arrest or even reverse pathology ${ }^{68}$ A major barrier to treating the CNS has been delivery of the normal protein to a sufficiently large area of the brain to have a therapeutic effect. Positive results have been shown in many experimental models of LSDs, providing a foundation for clinical trials (Supplementary Table 2 online). In naturally occurring large-animal models of LSDs, direct delivery of the transgene into the CNS after symptoms have developed has shown substantial reversal of established lesions, ${ }^{61,69}$ which raises hope that treatment of even advanced disease in patients with an LSD may provide some clinical benefit.

Three phase I clinical trials of gene therapy for genetic diseases of the CNS have been completed. ${ }^{70-72}$ The most promising results were in patients with X-linked adrenoleukodystrophy - a severe demyelinating disease caused by deficiency of the $A B C D I$ gene. In this trial, a lentivirus vector was used to transfect haematopoietic stem cells ex vivo with the $A B C D 1$ gene. ${ }^{72}$ These cells were subsequently infused into the patient, and the effects of the treatment were thought to be mediated by corrected monocytes migrating into the CNS. The other trials involved direct injection of AAV2 vector into the brains of patients with Canavan disease ${ }^{70}$ or a form of Batten disease. ${ }^{71}$ Both were phase I safety trials of AAV2 that involved too few injection sites to be therapeutic. New trials are under way to test AAV vector serotypes that may mediate increased spread of the transgene once delivered to the target area. However, true clinical improvement will probably require substantial increases in the amount of gene vector delivered, as well as significantly greater dispersion within the brain.

\section{Parkinson disease}

The most common neurodegenerative diseases, PD and Alzheimer disease (AD), affect the ageing population and are, therefore, an expanding demographic. ${ }^{73,74}$ Some neurodegenerative diseases, such as Huntington disease (HD), are entirely genetic, whereas others, including PD, AD and amyotrophic lateral sclerosis (ALS), occur more commonly in idiopathic than in familial forms. ${ }^{75-77}$ Consequently, gene therapy strategies for HD have concentrated on correcting the underlying gene defect and the resultant neurodegeneration, 
whereas in PD, AD and ALS, the focus has been on neuroprotection and repair. Here, we limit the discussion of gene therapy to $\mathrm{PD}$, although substantial progress has been made in preclinical studies towards gene therapy for HD and ALS, and a trial for gene therapy in AD is ongoing (Table 2).

PD is characterized by neurodegeneration of dopaminergic neurons in the substantia nigra that provide input to the basal ganglia. Three gene therapy strategies have evolved in the treatment of PD: induction of dopamine production, protection of substantia nigra neurons, and inhibition of the subthalamic nucleus through enhanced GABA signalling (Figure 4). The mainstay of therapy for patients with PD is pharmacological dopamine replacement. In patients with this condition, however, dopamine production in the nigrostriatal pathway is disproportionally reduced compared with that in the mesolimbic pathway. Pharmacological replacement of dopamine in the nigrostriatal pathway causes increased mesolimbic dopamine levels, leading to adverse effects such as poor impulse control. ${ }^{78}$

AADC, tyrosine hydroxylase and GCH1-Replacement of dopamine in an anatomically specific fashion, targeting nigrostriatal rather than mesolimbic pathways, could be a strategy to avoid the adverse effects of standard dopamine replacement strategies. Research efforts have been directed at targeted replacement of the enzymes and cofactors required to produce dopamine from tyrosine: aromatic amino acid decarboxylase (AADC), tyrosine hydroxylase and GTP cyclohydrolase. An equine infectious anaemia virus (EIAV) vector was created to deliver the genes encoding these proteins to rodent and primate models of PD. EIAV has a large transgene capacity, thereby enabling the vector to contain all three genes. This vector was shown to reverse functional deficits in pharmacological animal models of PD with substantia nigra lesions, ${ }^{79,80}$ and was taken forward into phase I-II trials of an escalating dose of putaminal injections in patients with PD. The results of this trial have not yet been published.

Two research groups have attempted to deliver the $A A D C$ gene in isolation to the putamen using an AAV vector. Because AADC uses levodopa as its substrate, dopamine production can be controlled by oral levodopa treatment in patients. In dopamine-depleted rodents and primates, AAV-mediated delivery of $A A D C$ resulted in long-term dopamine replacement and functional recovery when paired with oral levodopatherapy. ${ }^{81,82}$ A phase I trial of $A A D C$ delivery to the putamen using an AAV2 vector showed a $31 \%$ increase in putaminal dopamine as measured by PET scanning. Three patients were able to reduce their medication intake, but two experienced worsening of dyskinesia. ${ }^{83}$ A second study showed a $56 \%$ increase in dopamine activity above baseline on PET, and a $46 \%$ improvement in scores of motor function from baseline. ${ }^{84}$

Glutamate decarboxylase-Injection of GABA receptor agonists into the subthalamic nucleus has been shown to reduce the symptoms of PD by suppressing neuronal activity in this region. ${ }^{85}$ Prompted by this finding, researchers developed an AAV2 vector to express the $G A D$ gene, which encodes glutamate decarboxylase, the enzyme that converts glutamate to GABA. Delivery of this vector to the subthalamic nucleus in rodents and primates reduced excitatory output from the subthalamic nucleus, and improved tremor or dyskinesia. ${ }^{86,87}$ The improvement in motor functions might be the result of a change in the excitatory glutamatergic output from the subthalamic nucleus to inhibitory GABAergic output, increased GABA production in the subthalamic nucleus that reduced excitatory activity in the subthalamic nucleus, or increased GABAergic input to the subthalamic nucleus owing to retrograde transport of the $G A D$-containing vector from the subthalamic nucleus injection site to input nuclei that would inhibit activity in the subthalamic nucleus. ${ }^{86,87}$ 
A phase II trial of an AAV2 vector containing $G A D$, injected bilaterally into the subthalamic nuclei, improved Unified Parkinson Disease Rating Scale (UPDRS) scores by $36 \%$ from baseline at 6 months. ${ }^{88}$ Notably, however, $27 \%$ of patients in the treatment group were not included in the analysis. Nonetheless, this study is the first to demon strate the efficacy of gene therapy for a neurodegenerative disease in a randomized, placebo-controlled trial. Pharmacological dopamine replacement strategies and $G A D$ delivery to the subthalamic nucleus provide symptomatic relief, but do not slow or prevent dopaminergic neuron loss. Such surgical strategies should, therefore, only be considered for patients with late-stage refractory PD, given the lack of alternative therapeutic options in these circumstances. Dopamine replacement can also reduce dyskinesia resulting from the shift in dopamine production that occurs in the later stages of PD.

Neurturin-Neurturin (NRTN) is a neurotrophic factor that protects dopaminergic neurons from degeneration. AAV2 vector-mediated expression of $N R T N$ to protect the nigrostriatal dopamine system from degeneration was demonstrated in rodents and primates. ${ }^{89,90}$ Neuroprotection by NRTN expression is expected to prevent neuronal degeneration, and the first clinical trial was designed to detect improvements in motor function over a 1-year period. The anticipated improvement in motor function depends on an increase in dopamine production from the substantia nigra after putaminal injection with a vector containing the $N R T N$ gene. In a phase I trial, bilateral putaminal injection of the $A A V 2-N R T N$ vector increased UPDRS motor scores by $36 \%$ at 1 year compared with baseline, ${ }^{91}$ but no significant effect was detected at 1 year in a phase II trial. ${ }^{92}$ A second phase I-II trial, implementing transgene delivery to both the putamen and substantia nigra, is under way to examine higher doses of vector than in the first trial and with longer follow-up.

Histochemical analysis of postmortem tissue from the first phase II trial suggested poor retrograde delivery of $A A V 2-N R T N$ to the substantia nigra from the putamen, which prompted direct injection of AAV2-NRTN into the substantia nigra in the second phase II trial. Given that NRTN expression protects substantia nigra dopaminergic neurons against degeneration and promotes axonal regeneration, therapeutic NRTN delivery should probably be used early in the course of PD to maximize preservation of the substantia nigra.

\section{Epilepsy}

The term epilepsy encompasses disorders characterized by a persistent increase in neuronal excitability that is occasionally and unpredictably expressed as seizures. ${ }^{93}$ Seizures can be generalized, when the electrical activity occurs in bilaterally distributed networks, or focal, when activity is limited to one brain hemisphere. ${ }^{94}$ Epilepsies associated with generalized seizures are often caused by a genetic defect, whereas epilepsies with focal seizures generally result from a lesion in a specific brain region.

Gene therapy could be an option for patients with epilepsy, most probably for epilepsies caused by a lesion rather than those caused by a genetic defect. Genetic epilepsies usually result from inheritance of multiple susceptibility genes, and the associated pathology affects large brain areas, which would require widespread transfection of the brain with multiple genes. Lesional epilepsies are more amenable to gene therapy: first, a causal event is often identified, which provides a therapeutic window for prevention of disease during the latency period before spontaneous seizures occur (antiepileptogenic effect); second, seizuregenerating areas in the brain are restricted and easily identified. The unmet medical needs of patients with epilepsy include antiepileptogenic therapy (available drugs do not prevent the development of epilepsy in at-risk patients); new antiseizure therapies (available drugs fail to control seizures in one-third of patients and can have debilitating adverse effects); and disease-modifying therapies (available drugs do not prevent disease progression or the associated comorbidities). ${ }^{95}$ Gene therapy could help to address these needs. 
Gene therapy has been used to produce antiepileptogenic and antiseizure effects in experimental models of epilepsy (Table 3). Epileptogenesis may be alleviated by limiting the associated tissue damage. ${ }^{96}$ An HSV vector containing transgenes encoding two neurotrophic factors, fibroblast growth factor 2 and brain-derived neurotrophic factor was injected into the lesion area to supplement growth factor expression in the epileptogenic region during latency, which led to attenuation of cell loss and reduction of epileptogenesis. ${ }^{97-99}$

Antiseizure effects can be obtained by targeting the threshold for neuronal excitability; that is, by increasing the strength of inhibitory signals or reducing that of excitatory signals. Gene therapy intervention leading to re arrangement of GABA or glutamate receptor composition, so as to either increase or reduce the responsiveness of the receptors, produced antiseizure effects in animal models of epilepsy. ${ }^{100,101}$ These effects were, however, dependent on which cell population expressed the transgene: selective inhibition of excitatory, but not inhibitory, neurons produced antiseizure effects. ${ }^{91}$ Consistent with this finding, lentivirus vector-mediated overexpression of the potassium channel Kv1.1 preferentially in excitatory neurons, which reduced neuronal excitability, suppressed seizures in a rodent model of neocortical epilepsy. ${ }^{102}$

One way to circumvent the problem of cell-population selection is to induce constitutive secretion of seizure-inhibiting factors - for example, inhibitory neuropeptides-from transduced cells. Seizure control can be achieved without targeting specific cells if the receptors for these factors are present in brain tissue affected by epileptiform activity. Promising results for gene therapy in epilepsy have been obtained by local injection of vectors containing transgenes encoding the neuropeptides galanin or neuropeptide Y (NPY). In particular, NPY-expressing AAV vectors produced robust antiseizure effects and did not have adverse effects, ${ }^{103-111}$ which supports their application in the clinic.

Patients with partial epilepsies who have been selected for surgical resection of the epileptogenic area are ideal candidates for gene therapy. In such cases, brain pathology is focal, medical treatment has failed, and gene transfer of seizure-inhibitory factors (such as NPY) into the seizure-generating area might silence epileptic hyperactivity. These patients undergo implantation of depth electrodes for diagnosis before surgery, thereby obviating the need for ad hoc surgical intervention to inject the vector. In the event that gene therapy fails to prevent seizures, patients could undergo surgery as originally planned. Studies of gene therapy for epilepsy to date have been carried out in experimental animal models by injecting vectors directly into the epileptogenic region. However, a recombinant vector in which the capsid is a mixture of various AAV serotypes has been created that crosses only the seizure-compromised $\mathrm{BBB},{ }^{11}$ which suggests that selective targeting of seizuregenerating areas after intravenous administration of the vector may become possible.

\section{Brain tumours}

Glioblastoma multiforme, WHO grade IV, is the brain tumour with the most aggressive disease course. Advances in surgical techniques, radiotherapy and chemotherapy have increased the median survival of patients from 6-9 months to $18-21$ months. ${ }^{12}$ Fatal tumours that recur are thought to originate from surviving glioma cells and/or gliomainitiating cells after therapy. Advances in viral vector development in the 1980s, coupled with the idea that vectors injected into the brain might reach tumour cells not killed by other therapies, led to the development of gene therapy approaches for brain tumours in the 1990s (Table 4). ${ }^{113}$

Initial clinical trials used a nonreplicating retrovirus vector containing an HSV thymidine kinase gene, which sensitizes transfected cells to ganciclovir treatment. ${ }^{114-118}$ Researchers 
aimed to transduce tumour cells with thymidine kinase, and to kill the transfected cells with a systemically administered ganciclovir prodrug toxic to tumour cells. Trials moved rapidly from early phase I to a randomized controlled phase III trial, which failed to find improvement in patient survival, possibly owing to poor intratumoural distribution of the retroviral vector and subsequent immune responses to vector-producing cells. ${ }^{119}$

Developments in the technology to produce adenoviral vectors to high titres, and data that showed extensive intratumoural vector diffusion, led to phase I-II trials of adenoviral vectors containing the thymidine kinase transgene. ${ }^{120-123}$ The results of these early trials prompted a randomized control phase III trial that was completed in 2009. This trial failed to demonstrate a significant therapeutic effect. ${ }^{124}$ Other gene therapy strategies have included adenovirus-mediated expression of the tumour suppressor gene $p 53$ and augmentation of the localized immune response through adenoviral delivery of $I F N-\beta$. These approaches were not developed further, however, possibly owing to limited transduction of tumour cells with $p 53$ or toxicity from the adenovirus- $I F N-\beta$ construct. ${ }^{125,126}$ Nevertheless, the safety of viral vectors, which has been demonstrated in clinical trials, has led to the proposed use of replication-competent oncolytic viruses to increase intratumoural vector diffusion and tumour killing. Replication-competent HSV-1, adenovirus, reovirus, measles virus, retrovirus, and Newcastle disease virus are currently being tested as vectors in early-phase clinical trials. ${ }^{127-130}$

Research continues to improve vector delivery and transgene expression, as well as vector specificity for tumour cell delivery and targeting. A promising method is the use of MRI to guide viral vector and transgene delivery, and to track vector distribution. Strategies include construction of a vector to express the ferritin reporter gene, which is detectable by MRI, and covalent binding of the viral vector to superparamagnetic iron oxide nanoparticles for detection by MRI. ${ }^{131,132}$ Focused ultrasound combined with MRI to focally disrupt the BBB has been proposed to increase delivery of viral vectors to specific brain regions in a noninvasive manner via the bloodstream. ${ }^{133}$ Such strategies allow controlled and focused therapeutic delivery to brain tumours.

Despite technical advances, changes to regulatory procedures, and promising results from translational studies in the past 20 years, a breakthrough in gene therapy for treatment of patients with glioblastoma multiforme is still awaited. Gene therapy strategies currently in phase I-II clinical trials include oncolytic wild-type viruses (measles virus), oncolytic viruses containing molecular therapeutics (retroviruses encoding cytosine deaminase), and adenoviral vectors that provide a combination of genes encoding cytotoxic factors and immune-stimulatory cytokines (HSV-1-thymidine kinase and Flt3L; IND14574—study NCT01811992). ${ }^{134-141}$ Safety of these gene therapy strategies in early phase I-II trials provides hope for success in randomized phase III trials and improved therapeutic options for glioblastoma multiforme.

\section{Conclusions}

The aim of this Review has been to provide an overview of promising gene therapy strategies for diseases of the nervous system. PNS diseases are the most likely to have approved treatments available within the next decade. These diseases include sensory nerve degeneration due to diabetes or chemotherapy; functional deficits of vision, hearing and smell; and chronic pain conditions. Development of gene therapy for CNS diseases is far more challenging as gene delivery trials have required surgical procedures, and the pathogenesis of many of these diseases is multifactorial and poorly understood. Moreover, CNS diseases often involve large brain regions or even the entire brain, suggesting the need for widespread gene delivery. Results in animal models, however, indicate that alternative 
routes of delivery to intraparenchymal injection, combined with novel properties of vectors and proteins, might enable correction of whole-brain pathology. We anticipate that most of the scientific and technical hurdles that remain to the clinical application of gene therapy for neurological disorders will be overcome.

Other barriers to the development of gene therapy approaches include regulatory and commercial issues. It is recognized that current regulations in Europe and the USA make clinical trials of gene therapy very costly and time-consuming. In addition, we suggest that in a competitive commercial environment, the potential for disruption of existing markets by new gene therapy applications might render the biopharmaceutical industry reluctant to contribute to the development of innovative technological advances.

Opinion regarding gene therapy has evolved from it being a highly touted gene-correction strategy that can be achieved with ease, to the belief that the risk from a replicationcompetent vector is too great for its application to patients who are not desperately sick, to a more sober view that gene therapy might be an effective treatment or cure for some of our most difficult-to-treat diseases. Application of gene therapy to PNS disorders is rapidly maturing, whereas application to the CNS will require breakthroughs in research on targeted gene delivery, controlled transgene expression, and methods to facilitate widespread correction of brain pathology. With continued commitment from researchers in this field, gene therapy could in future make important contributions to therapeutic options for diverse neurological diseases.

\section{Supplementary Material}

Refer to Web version on PubMed Central for supplementary material.

\section{Acknowledgments}

The authors' research is supported by grants from, the European Community (PIAPP-GA-2011-285827, [EPIXCHANGE Project] to M. Simonato) and from the, NIH (CA119298, NS40923 and DK044935 to, J. C. Glorioso; EY023177 and EY019861 to, J. Bennett; NS038850 and NS069378 to D. J. Fink; NS038690, DK063973, NS056243, NS029390, DK047757, OD010939 and TR000003 to, J. H. Wolfe; NS052465, NS052465-04S1, NS057711 and NS074387 to M. G. Castro and, 1NS054193, NS061107 and TR000433 to, P. R. Lowenstein). The authors thank A. Pizzirani, and J. Coulter for preparation of the figures, before submission.

\section{References}

1. Elsabahy M, Nazarali A, Foldvari M. Non-viral nucleic acid delivery: key challenges and future directions. Curr. Drug Deliv. 2011; 8:235-244. [PubMed: 21291381]

2. Goncalves MA. Adeno-associated virus: from defective virus to effective vector. Virol. J. 2005; 2:43. [PubMed: 15877812]

3. Matrai J, Chuah MK, VandenDriessche T. Recent advances in lentiviral vector development and applications. Mol. Ther. 2010; 18:477-490. [PubMed: 20087315]

4. Nayak S, Herzog RW. Progress and prospects: immune responses to viral vectors. Gene Ther. 2010; 17:295-304. [PubMed: 19907498]

5. Foust KD, et al. Intravascular AAV9 preferentially targets neonatal neurons and adult astrocytes. Nat. Biotechnol. 2009; 27:59-65. [PubMed: 19098898]

6. Duque $\mathrm{S}$, et al. Intravenous administration of self-complementary AAV9 enables transgene delivery to adult motor neurons. Mol. Ther. 2009; 7:1187-1196. [PubMed: 19367261]

7. Gray SJ, et al. Preclinical differences of intravascular AAV9 delivery to neurons and glia: a comparative study of adult mice and nonhuman primates. Mol. Ther. 2011; 19:1058-1069. [PubMed: 21487395]

8. Pulicherla N, et al. Engineering liver-detargeted AAV9 vectors for cardiac and musculoskeletal gene transfer. Mol. Ther. 2011; 6:1070-1078. [PubMed: 21364538] 
9. Bennett, et al. Further reduction in adenovirus vector-mediated liver transduction without largely affecting transgene expression in target organ by exploiting microrna-mediated regulation and the Cre-loxP recombination system. Mol. Pharm. 9:3452-3463.

10. Chen YH, Chang M, Davidson BL. Molecular signatures of disease brain endothelia provide new sites for CNS-directed enzyme therapy. Nat. Med. 2009; 15:1215-1218. [PubMed: 19749771]

11. Maheshri N, Koerber JT, Kaspar BK, Schaffer DV. Directed evolution of adeno-associated virus yields enhanced gene delivery vectors. Nat. Biotechnol. 2006; 24:198-204. [PubMed: 16429148]

12. Gray SJ, et al. Directed evolution of a novel adeno-associated virus (AAV) vector that crosses the seizure-compromised blood-brain barrier (BBB). Mol. Ther. 2010; 18:570-578. [PubMed: 20040913]

13. Hermening S, Kugler S, Bahr M, Isenmann S. Improved high-capacity adenoviral vectors for highlevel neuron-restricted gene transfer to the CNS. J. Virol. Methods. 2006; 136:30-37. [PubMed: 16672163]

14. Gray SJ, et al. Optimizing promoters for recombinant adeno-associated virus-mediated gene expression in the peripheral and central nervous system using self-complementary vectors. Hum. Gene Ther. 2011; 9:1143-1153. [PubMed: 21476867]

15. Qin JY, et al. Systematic comparison of constitutive promoters and the doxycycline-inducible promoter. PLoS ONE. 2010; 5:e10611. [PubMed: 20485554]

16. Husain T, Passini MA, Parente MK, Fraser NW, Wolfe JH. Long-term AAV vector gene and protein expression in mouse brain from a small pan-cellular promoter is similar to neural cell promoters. Gene Ther. 2009; 16:927-932. [PubMed: 19458648]

17. Kugler S, et al. Neuron-specific expression of therapeutic proteins: evaluation of different cellular promoters in recombinant adenoviral vectors. Mol. Cell Neurosci. 2001; 17:78-96. [PubMed: 11161471]

18. Peel AL, Zolotukhin S, Schrimsher GW, Muzyczka N, Reier PJ. Efficient transduction of green fluorescent protein in spinal cord neurons using adeno-associated virus vectors containing cell type-specific promoters. Gene Ther. 1997; 4:16-24. [PubMed: 9068791]

19. Kügler S, Lingor P, Schöll U, Zolotukhin S, Bähr M. Differential transgene expression in brain cells in vivo and in vitro from AAV-2 vectors with small transcriptional control units. Virology. 2003; 311:89-95. [PubMed: 12832206]

20. Lee Y, Messing A, Su M. \& Brenner, M? GFAP promoter elements required for region-specific and astrocyte-specific expression. Glia. 2008; 56:481-493. [PubMed: 18240313]

21. den Hollander AI, Black A, Bennett J, Cremers FP. Lighting a candle in the dark: advances in genetics and gene therapy of recessive retinal dystrophies. J. Clin. Invest. 2010; 120:3042-3053. [PubMed: 20811160]

22. Farrar GJ, Millington-Ward S, Chadderton N, Humphries P, Kenna PF. Gene-based therapies for dominantly inherited retinopathies. Gene Ther. 2012; 19:137-144. [PubMed: 22089493]

23. Millington-Ward S, et al. Suppression and replacement gene therapy for autosomal dominant disease in a murine model of dominant retinitis pigmentosa. Mol. Ther. 2011; 19:642-649. [PubMed: 21224835]

24. Jiang L, et al. Long-term RNA interference gene therapy in a dominant retinitis pigmentosa mouse model. Proc. Natl Acad. Sci. USA. 2011; 108:18476-18481. [PubMed: 22042849]

25. Lai YK, et al. Potential long-term inhibition of ocular neovascularisation by recombinant adenoassociated virus-mediated secretion gene therapy. Gene Ther. 2002; 9:804-813. [PubMed: 12040462]

26. Jomary C, Jones SE. Induction of functional photoreceptor phenotype by exogenous $\mathrm{Crx}$ expression in mouse retinal stem cells. Invest. Ophthalmol. Vis. Sci. 2008; 49:429-437. [PubMed: 18172122]

27. Gubbels SP, Woessner DW, Mitchell JC, Ricci AJ, Brigande JV. Functional auditory hair cells produced in the mammalian cochlea by in utero gene transfer. Nature. 2008; 455:537-541. [PubMed: 18754012]

28. Izumikawa M, et al. Auditory hair cell replacement and hearing improvement by Atohl gene therapy in deaf mammals. Nat. Med. 2005; 11:271-276. [PubMed: 15711559] 
29. Busskamp V, Picaud S, Sahel JA, Roska B. Optogenetic therapy for retinitis pigmentosa. Gene Ther. 2012; 19:169-175. [PubMed: 21993174]

30. Ashtari M, et al. The human visual cortex responds to gene therapy-mediated recovery of retinal function. J. Clin. Invest. 2011; 121:2160-2168. [PubMed: 21606598]

31. Hauswirth WW, et al. Treatment of leber congenital amaurosis due to RPE65 mutations by ocular subretinal injection of adeno-associated virus gene vector: short-term results of a phase I trial. Human Gene Ther. 2008; 19:979-990. [PubMed: 18774912]

32. Bainbridge JW, et al. Effect of gene therapy on visual function in Leber's congenital amaurosis. N. Engl. J. Med. 2008; 358:2231-2239. [PubMed: 18441371]

33. Maguire AM, et al. Safety and efficacy of gene transfer for Leber's congenital amaurosi. N. Engl. J. Med. 2008; 358:2240-2248. [PubMed: 18441370]

34. Cremers FP, van de Pol DJ, van Kerkhoff LP, Wieringa B, Ropers HH. Cloning of a gene that is rearranged in patients with choroideraemia. Nature. 1990; 347:674-677. [PubMed: 2215697]

35. Dryja TP, et al. A point mutation of the rhodopsin gene in one form of retinitis pigmentosa. Nature. 1990; 343:364-366. [PubMed: 2137202]

36. Farrar GJ, et al. Autosomal dominant retinitis pigmentosa: linkage to rhodopsin and evidence for genetic heterogeneity. Genomics. 1990; 8:35-40. [PubMed: 2081598]

37. Akil O, et al. Restoration of hearing in the VGLUT3 knockout mouse using virally mediated gene therapy. Neuron. 2012; 75:283-293. [PubMed: 22841313]

38. Lentz, JJ., et al. Rescue of hearing and vestibular function by antisense oligonucleotides in a mouse model of human deafness. Nat. Med. http://dx/doi.org/10.1038/nm.3106

39. McIntyre JC, et al. Gene therapy rescues cilia defects and restores olfactory function in a mammalian ciliopathy model. Nat. Med. 2012; 18:1423-1428. [PubMed: 22941275]

40. Glorioso JC, Fink DJ. Herpes vector-mediated gene transfer in treatment of diseases of the nervous system. Annu. Rev. Microbiol. 2004; 58:253-271. [PubMed: 15487938]

41. Mata M, Glorioso JC, Fink DJ. Gene therapy: novel treatments for polyneuropathy and chronic pain. Curr. Neurol. Neurosci. Rep. 2004; 4:1-2. [PubMed: 14683620]

42. Goss JR, et al. HSV delivery of a ligand-regulated endogenous ion channel gene to sensory neurons results in pain control following channel activation. Mol. Ther. 2011; 19:500-506. [PubMed: 21081904]

43. Goss JR, et al. Antinociceptive effect of a genomic herpes simplex virus-based vector expressing human proenkephalin in rat dorsal root ganglion. Gene Ther. 2001; 8:551-556. [PubMed: 11319622]

44. Goss JR, et al. Herpes vector-mediated expression of proenkephalin reduces bone cancer pain. Ann. Neurol. 2002; 52:662-665. [PubMed: 12402268]

45. Hao S, Mata M, Goins W, Glorioso JC, Fink DJ. Transgene-mediated enkephalin release enhances the effect of morphine and evades tolerance to produce a sustained antiallodynic effect in neuropathic pain. Pain. 2003; 102:135-142. [PubMed: 12620604]

46. Hao S, et al. Gene transfer of glutamic acid decarboxylase reduces neuropathic pain. Ann. Neurol. 2005; 57:914-918. [PubMed: 15929041]

47. Chattopadhyay M, Mata M, Fink DJ. Vector-mediated release of GABA attenuates pain-related behaviors and reduces NaV1.7 in DRG neurons. Eur. J. Pain. 2011; 15:913-920. [PubMed: 21486703]

48. Hao S, Mata M, Glorioso JC, Fink DJ. HSV-mediated expression of interleukin-4 in dorsal root ganglion neurons reduces neuropathic pain. Mol. Pain. 2006; 2:6. [PubMed: 16503976]

49. Zhou Z, Peng X, Hao S, Fink DJ, Mata M. HSV-mediated transfer of interleukin-10 reduces inflammatory pain through modulation of membrane tumor necrosis factor $\mathrm{a}$ in spinal cord microglia. Gene Ther. 2008; 15:183-190. [PubMed: 18033311]

50. Lau D, et al. Herpes simplex virus vector-mediated expression of interleukin-10 reduces belowlevel central neuropathic pain after spinal cord injury. Neurorehabil. Neural Repair. 2012; 26:889897. [PubMed: 22593113] 
51. Goss JR, et al. Herpes simplex-mediated gene transfer of nerve growth factor protects against peripheral neuropathy in streptozotocin-induced diabetes in the mouse. Diabetes. 2002; 51:22272232. [PubMed: 12086954]

52. Chattopadhyay M, et al. Protective effect of HSV-mediated gene transfer of nerve growth factor in pyridoxine neuropathy demonstrates functional activity of trkA receptors in large sensory neurons of adult animals. Eur. J. Neurosci. 2003; 17:732-740. [PubMed: 12603263]

53. Chattopadhyay $\mathrm{M}$, et al. Protective effect of herpes simplex virus-mediated neurotrophin gene transfer in cisplatin neuropathy. Brain. 2004; 127:929-939. [PubMed: 14749293]

54. Chattopadhyay M, Walter C, Mata M, Fink DJ. Neuroprotective effect of herpes simplex virusmediated gene transfer of erythropoietin in hyperglycemic dorsal root ganglion neurons. Brain. 2009; 132:879-888. [PubMed: 19244253]

55. Chattopadhyay M, et al. Prolonged preservation of nerve function in diabetic neuropathy in mice by herpes simplex virus-mediated gene transfer. Diabetologia. 2007; 50:1550-1558. [PubMed: 17508196]

56. Wu Z, Mata M, Fink DJ. Prolonged regulatable expression of EPO from an HSV vector using the LAP2 promoter element. Gene Ther. 2012; 19:1107-1113. [PubMed: 22089494]

57. Fink DJ, et al. Gene therapy for pain: results of a phase I clinical trial. Ann. Neurol. 2011; 70:207212. [PubMed: 21796661]

58. Wolfe D, Mata M, Fink DJ. A human trial of HSV-mediated gene transfer for the treatment of chronic pain. Gene Therapy. 2009; 14:455-460. [PubMed: 19242524]

59. Harper SQ, et al. RNA interference improves motor and neuropathological abnormalities in a Huntington's disease mouse model. Proc. Natl Acad. Sci. USA. 2005; 16:5820-5825. [PubMed: 15811941]

60. Wolfe JH. Gene therapy in large animal models of human genetic diseases. ILAR J. 2009; 50:107111. [PubMed: 19293455]

61. Vite $\mathrm{CH}$, et al. Effective gene therapy for an inherited CNS disease in a large animal model. Ann. Neurol. 2005; 57:355-364. [PubMed: 15732095]

62. Berges BK, et al. Widespread correction of lysosomal storage in the mucopolysaccharidosis type VII mouse brain with a herpes simplex virus type 1 vector expressing $\beta$-glucuronidase. Mol. Ther. 2006; 13:859-869. [PubMed: 16515890]

63. Cearley CN, Wolfe JH. A single injection of an adeno-associated virus vector into nuclei with divergent connections results in widespread vector distribution in the brain and global correction of a neurogenetic disease. J. Neurosci. 2007; 27:9928-9940. [PubMed: 17855607]

64. Baek RC, et al. AAV-mediated gene delivery in adult GM1-gangliosidosis mice corrects lysosomal storage in CNS and improves survival. PloS ONE. 2010; 5:e13468. [PubMed: 20976108]

65. Lui G, Martins IH, Wemmie JA, Chiorini JA, Davidson BL. Functional correction of CNS phenotypes in a lysosomal storage disease model using adeno-associated virus type 4 vectors. J. Neurosci. 2005; 25:9321-9327. [PubMed: 16221840]

66. Donsante A, et al. ATP7A gene addition to the choroid plexus results in long-term rescue of the lethal copper transport defect in a Menkes disease mouse model. Mol. Ther. 2011; 19:2114-2123. [PubMed: 21878905]

67. Watson DJ, Wolfe JH. Lentiviral vectors for gene transfer to the central nervous system. Applications in lysosomal storage disease animal models. Meth. Mol. Med. 2003; 76:383-403.

68. Cearley, CN.; Wolfe, JH. Encyclopedia of Neuroscience. Squire, LR., editor. Academic Press; Oxford: 2009. p. 179-188.

69. Ellinwood NM, et al. Safe, efficient, and reproducible gene therapy of the brain in the dog models of Sanfilippo and Hurler syndromes. Mol. Ther. 2011; 19:251-259. [PubMed: 21139569]

70. Leone P, et al. Aspartoacylase gene transfer to the mammalian central nervous system with therapeutic implications for Canavan disease. Ann. Neurol. 2000; 48:27-38. [PubMed: 10894213]

71. Worgall S, et al. Treatment of late infantile neuronal ceroid lipofuscinosis by CNS administration of a serotype 2 adeno-associated virus expressing CLN2 cDNA. Human Gene Ther. 2008; 19:463474. [PubMed: 18473686]

72. Cartier N, et al. Hematopoietic stem cell gene therapy with a lentiviral vector in X-linked adrenoleukodystrophy. Science. 2009; 326:818-823. [PubMed: 19892975] 
73. Brookmeyer R, Gray S. Method for projecting the incidence and prevalence of chronic diseases in aging populations; application to Alzheimer's disease. Stat. Med. 2000; 19:1481-1493. [PubMed: 10844713]

74. Holtzman DM, et al. Alzheimer's disease: the challenge of the second century. Sci. Transl. Med. 2011; 3 77sr71.

75. Wirdefeldt K, Adami H-O, Cole P, Trichopoulos D, Mandel J. Epidemiology and etiology of Parkinson's disease; a review of the evidence. Eur. J. Epidemiol. 2011; 26:S1-S58. [PubMed: 21626386]

76. Siddique T, Ajroud-Driss S. Familial amyotrophic lateral sclerosis, a historical perspective. Acta Myol. 2011; 2:117-120. [PubMed: 22106714]

77. [No authors listed] A novel gene containing a trinucleotide repeat that is expanded and unstable on Huntington disease chromosomes. The Huntington's Disease Collaborative Research Group. Cell. 1993; 72:971-983. [PubMed: 8458085]

78. Lang AE, Lozano AMParkinson's disease. Second of two parts. N. Engl. J. Med. 1998; 339:11301143. [PubMed: 9770561]

79. Azzouz M, et al. Multicistronic lentiviral vector-mediated striatal gene transfer of aromatic l-amino acid decarboxylase, tyrosine hydroxylase, and GTP cyclohydrolase I induces sustained transgene expression, dopamine production, and functional improvement in a rat model of Parkinson's disease. J. Neurosci. 2002; 22:10302-10312. [PubMed: 12451130]

80. Jarraya B, et al. Dopamine gene therapy for Parkinson's disease in a nonhuman primate without associated dyskinesia. Sci. Transl. Med. 2009; 12 ra4.

81. Leff SE, Spratt SK, Snyder RO, Mandel RJ. Long-term restoration of striatal l-aromatic amino acid decarboxylase activity using recombinant adeno-associated viral vector gene transfer in a rodent model of Parkinson's disease. Neuroscience. 1999; 92:185-196. [PubMed: 10392841]

82. Bankiewicz KS, et al. Long-term clinical improvement in MPTP-lesioned primates after gene therapy with AAV-hAADC. Mol. Ther. 2006; 14:564-570. [PubMed: 16829205]

83. Christine $\mathrm{CW}$, et al. Safety and tolerability of putaminal $A A D C$ gene therapy for Parkinson disease. Neurology. 2009; 73:1662-1669. [PubMed: 19828868]

84. Muramatsu S, et al. A phase I study of aromatic L-amino acid decarboxylase gene therapy for Parkinson's disease. Mol. Ther. 2010; 18:1731-1735. [PubMed: 20606642]

85. Levy R, et al. Lidocaine and muscimol microinjections in subthalamic nucleus reverse Parkinsonian symptoms. Brain. 2001; 124:2105-2118. [PubMed: 11571226]

86. Luo J, et al. Subthalamic GAD gene therapy in a Parkinson's disease rat model. Science. 2002; 298:425-429. [PubMed: 12376704]

87. Emborg ME, et al. Subthalamic glutamic acid decarboxylase gene therapy: changes in motor function and cortical metabolism. J. Cereb. Blood Flow Metab. 2007; 27:501-509. [PubMed: 16835631]

88. LeWitt PA, et al. AAV2-GAD gene therapy for advanced Parkinson's disease: a double-blind, sham-surgery controlled, randomised trial. Lancet Neurol. 2011; 10:309-319. [PubMed: 21419704]

89. Oiwa Y, Yoshimura R, Nakai K, Itakura T. Dopaminergic neuroprotection and regeneration by neurturin assessed by using behavioral, biochemical and histochemical measurements in a model of progressive Parkinson's disease. Brain Res. 2002; 947:271-283. [PubMed: 12176170]

90. Kordower JH, et al. Delivery of neurturin by AAV2 (CERE-120)-mediated gene transfer provides structural and functional neuroprotection and neurorestoration in MPTP-treated monkeys. Ann. Neurol. 2006; 60:706-715. [PubMed: 17192932]

91. Marks WJ Jr. et al. Safety and tolerability of intraputaminal delivery of CERE-120 (adenoassociated virus serotype 2-neurturin) to patients with idiopathic Parkinson's disease: an openlabel, phase I trial. Lancet Neurol. 2008; 7:400-408. [PubMed: 18387850]

92. Marks WJ Jr. et al. Gene delivery of AAV2-neurturin for Parkinson's disease: a double-blind, randomised, controlled trial. Lancet Neurol. 2010; 9:1164-1172. [PubMed: 20970382]

93. Fisher RS, et al. Epileptic seizures and epilepsy: definitions proposed by the International League Against Epilepsy (ILAE) and the International Bureau for Epilepsy (IBE). Epilepsia. 2005; 46:470-472. [PubMed: 15816939] 
94. Berg AT, et al. Revised terminology and concepts for organization of seizures and epilepsies: report of the ILAE commission on classification and terminology, 2005-2009. Epilepsia. 2010; 51:676-685. [PubMed: 20196795]

95. Galanopoulou AS, et al. Identification of new epilepsy treatments: issues in preclinical methodology. Epilepsia. 2012; 53:571-582. [PubMed: 22292566]

96. Simonato M, Tongiorgi E, Kokaia M. Angels and demons: neurotrophic factors and epilepsy. Trends Pharmacol. Sci. 2006; 27:631-638. [PubMed: 17055067]

97. Paradiso B, et al. Localized delivery of fibroblast growth factor-2 and brain-derived neurotrophic factor reduces spontaneous seizures in an epilepsy model. Proc. Natl Acad. Sci. USA. 2009; 106:7191-7196. [PubMed: 19366663]

98. Bovolenta R, et al. Hippocampal FGF-2 and BDNF overexpression attenuates epileptogenesisassociated neuroinflammation and reduces spontaneous recurrent seizures. J. Neuroinflammation. 2010; 7:81. [PubMed: 21087489]

99. Paradiso B, et al. Localized overexpression of FGF-2 and BDNF in hippocampus reduces mossy fiber sprouting and spontaneous seizures up to 4 weeks after pilocarpine-induced status epilepticus. Epilepsia. 2011; 52:572-578. [PubMed: 21269288]

100. Haberman R, et al. Therapeutic liabilities of in vivo viral vector tropism: adeno-associated virus vectors, NMDAR1 antisense, and focal seizure sensitivity. Mol. Ther. 2002; 6:495-500. [PubMed: 12377191]

101. Raol YH, et al. Enhancing $\mathrm{GABA}_{\mathrm{A}}$ receptor a 1 subunit levels in hippocampal dentate gyrus inhibits epilepsy development in an animal model of temporal lobe epilepsy. J. Neurosci. 2006; 26:11342-11346. [PubMed: 17079662]

102. Wykes RC, et al. Optogenetic and potassium channel gene therapy in a rodent model of focal neocortical epilepsy. Sci. Transl. Med. 2012; 161 161ra152.

103. Haberman RP, Samulski RJ, McCown TJ. Attenuation of seizures and neuronal death by adenoassociated virus vector galanin expression and secretion. Nat. Med. 2003; 9:1076-1080. [PubMed: 12858168]

104. Lin EJ, et al. Recombinant AAV-mediated expression of galanin in rat hippocampus suppresses seizure development. Eur. J. Neurosci. 2003; 18:2087-2092. [PubMed: 14622242]

105. Richichi C, et al. Anticonvulsant and antiepileptogenic effects mediated by adeno-associated virus vector neuropeptide Y expression in the rat hippocampus. J. Neurosci. 2004; 24:30513059. [PubMed: 15044544]

106. McCown TJ. Adeno-associated virus-mediated expression and constitutive secretion of galanin suppresses limbic seizure activity in vivo. Mol. Ther. 2006; 14:63-68. [PubMed: 16730475]

107. Foti S, Haberman RP, Samulski RJ, McCown TJ. Adeno-associated virus-mediated expression and constitutive secretion of NPY or NPY13-36 suppresses seizure activity in vivo. Gene Ther. 2007; 14:1534-1536. [PubMed: 17713567]

108. Noe F, et al. Neuropeptide Y gene therapy decreases chronic spontaneous seizures in a rat model of temporal lobe epilepsy. Brain. 2008; 131:1506-1515. [PubMed: 18477594]

109. Sorensen AT, et al. Hippocampal NPY gene transfer attenuates seizures without affecting epilepsy-induced impairment of LTP. Exp. Neurol. 2009; 215:328-333. [PubMed: 19038255]

110. Noe F, et al. Anticonvulsant effects and behavioural outcomes of rAAV serotype 1 vectormediated neuropeptide Y overexpression in rat hippocampus. Gene Ther. 2010; 17:643-652. [PubMed: 20220782]

111. Woldbye DP, et al. Adeno-associated viral vector-induced overexpression of neuropeptide Y Y2 receptors in the hippocampus suppresses seizures. Brain. 2010; 133:2778-2788. [PubMed: 20688813]

112. Grossman SA, et al. Survival of patients with newly diagnosed glioblastoma treated with radiation and temozolomide in research studies in the United States. Clin. Cancer Res. 2010; 8:2443-2449. [PubMed: 20371685]

113. Castro M, et al. Gene therapy and targeted toxins for glioma. Curr. Gene Ther. 2012; 11:155-180. [PubMed: 21453286]

114. Ram Z, et al. Therapy of malignant brain tumors by intratumoral implantation of retroviral vectorproducing cells. Nat. Med. 1997; 3:1354-1361. [PubMed: 9396605] 
115. Izquierdo M, et al. Human malignant brain tumor response to herpes simplex thymidine kinase (HSVtk)/ganciclovir gene therapy. Gene Ther. 1996; 3:491-495. [PubMed: 8789798]

116. Shand N, et al. A phase 1-2 clinical trial of gene therapy for recurrent glioblastoma multiforme by tumor transduction with the herpes simplex thymidine kinase gene followed by ganciclovir. GLI328 European-Canadian Study Group. Hum. Gene Ther. 1999; 10:2325-2335. [PubMed: 10515452]

117. Klatzmann, DAphase; I/II, study of herpes simplex virus type 1 thymidine kinase "suicide" gene therapy for recurrent glioblastoma, et al. Study Group on Gene Therapy for Glioblastoma. Hum. Gene Ther. 1998; 9:2595-2604. [PubMed: 9853526]

118. Prados MD, et al. Treatment of progressive or recurrent glioblastoma multiforme in adults with herpes simplex virus thymidine kinase gene vector-producer cells followed by intravenous ganciclovir administration: a phase I/II multi-institutional trial. J. Neurooncol. 2003; 65:269-278. [PubMed: 14682377]

119. Rainov NG. A phase III clinical evaluation of herpes simplex virus type 1 thymidine kinase and ganciclovir gene therapy as an adjuvant to surgical resection and radiation in adults with previously untreated glioblastoma multiforme. Hum. Gene Ther. 2000; 11:2389-2401. [PubMed: 11096443]

120. Trask TW, et al. Phase I study of adenoviral delivery of the HSV-tk gene and ganciclovir administration in patients with current malignant brain tumors. Mol. Ther. 2000; 1:195-203. [PubMed: 10933931]

121. Germano IM, Fable J, Gultekin SH, Silvers A. Adenovirus/herpes simplex-thymidine kinase/ ganciclovir complex: preliminary results of a phase I trial in patients with recurrent malignant gliomas. J. Neurooncol. 2003; 65:279-289. [PubMed: 14682378]

122. Immonen A, et al. AdvHSV-tk gene therapy with intravenous ganciclovir improves survival in human malignant glioma: a randomised, controlled study. Mol. Ther. 2004; 10:967-972. [PubMed: 15509514]

123. Sandmair AM, et al. Thymidine kinase gene therapy for human malignant glioma, using replication-deficient retroviruses or adenoviruses. Hum. Gene Ther. 2000; 11:2197-2205. [PubMed: 11084677]

124. Good Clinical Practice Inspectors Working Group. Reflection paper on GCP compliance in relation to trial master files (paper and/or electronic) of management, audit and inspection of clinical trials. European Medicines Agency. 2013. [online], http://www.ema.europa.eu/docs/ en_GB/document_library/Scientific_guideline/2013/02/WC500138893.pdf

125. Chiocca EA, et al. A phase I trial of Ad.hIFN- $\beta$ gene therapy for glioma. Mol. Ther. 2008; 16:618-626. [PubMed: 18180770]

126. Lang FF, et al. Phase I trial of adenovirus-mediated p53 gene therapy for recurrent glioma: biological and clinical results. J. Clin. Oncol. 2003; 21:2508-2518. [PubMed: 12839017]

127. Papanastassiou V, et al. The potential for efficacy of the modified (ICP 34.5 herpes simplex virus HSV1716 following intratumoural injection into human malignant glioma: a proof of principle study. Gene Ther. 2002; 9:398-406. [PubMed: 11960316]

128. Chiocca EA, et al. A phase I open-label, dose-escalation, multi-institutional trial of injection with an E1B-attenuated adenovirus, ONYX-015, into the peritumoral region of recurrent malignant gliomas, in the adjuvant setting. Mol. Ther. 2004; 10:958-966. [PubMed: 15509513]

129. Forsyth $\mathrm{P}$, et al. A phase I trial of intratumoral administration of reovirus in patients with histologically confirmed recurrent malignant gliomas. Mol. Ther. 2008; 16:627-632. [PubMed: 18253152]

130. Markert JM, et al. Phase Ib trial of mutant herpes simplex virus G207 inoculated pre-and posttumor resection for recurrent GBM. Mol. Ther. 2009; 17:199-207. [PubMed: 18957964]

131. Yun J, et al. A novel adenoviral vector labeled with superparamagnetic iron oxide nanoparticles for real-time tracking of viral delivery. J. Clin. Neurosci. 2012; 19:875-880. [PubMed: 22516547]

132. Vande Velde G, et al. Evaluation of the specificity and sensitivity of ferritin as an MRI reporter gene in the mouse brain using lentiviral and adeno-associated viral vectors. Gene Ther. 2011; 18:594-605. [PubMed: 21346786] 
133. Thevenot E, et al. Targeted delivery of self-complementary adeno-associated virus serotype 9 to the brain, using magnetic resonance imaging-guided focused ultrasound. Hum. Gene Ther. 2012; 23:1144-1155. [PubMed: 22838844]

134. Markert JM, et al. Conditionally replicating herpes simplex virus mutant, G207 for the treatment of malignant glioma: results of a phase I trial. Gene Ther. 2000; 7:867-874. [PubMed: 10845725]

135. Rampling R, et al. Toxicity evaluation of replication-competent herpes simplex virus (ICP 34.5 null mutant 1716) in patients with recurrent malignant glioma. Gene Ther. 2000; 7:859-866. [PubMed: 10845724]

136. Freeman AI, et al. Phase I/II trial of intravenous NDV-HUJ oncolytic virus in recurrent glioblastoma multiforme. Mol. Ther. 2006; 13:221-228. [PubMed: 16257582]

137. Ali S, et al. Combined immunostimulation and conditional cytotoxic gene therapy provide longterm survival in a large glioma model. Cancer Res. 2005; 65:7194-7204. [PubMed: 16103070]

138. Chiocca EA, et al. Phase IB study of gene-mediated cytotoxic immunotherapy adjuvant to upfront surgery and intensive timing radiation for malignant glioma. J. Clin. Oncol. 2011; 29:36113619. [PubMed: 21844505]

139. Palu G, et al. Gene therapy of glioblastoma multiforme via combined expression of suicide and cytokine genes: a pilot study in humans. Gene Ther. 1999; 6:330-337. [PubMed: 10435083]

140. Curtin JF, et al. HMGB1 mediates endogenous TLR2 activation and brain tumor regression. PLoS Med. 2009; 6:e10. [PubMed: 19143470]

141. US National Institutes of Health? ClinicalTrials. gov. 2013. [online], http://clinicaltrials.gov/ct2/ show/NCT01811992

142. Kells AP, et al. Regeneration of the MPTP-lesioned dopaminergic system after convectionenhanced delivery of AAV2-GDNF. J. Neurosci. 2010; 28:9567-9577. [PubMed: 20631185]

143. Bartus RT, et al. The safety and feasibility of combined substantia nigral putaminal stereotactic targetingof AAV2-neurturin (CERE120) in Parkinson's disease. Neurology. in press.

144. McBride JL, et al. Preclinical safety of RNAi-mediated HTT suppression in the rhesus macaque as a potential therapy for Huntington's disease. Mol. Ther. 2011; 12:2152-2162. [PubMed: 22031240]

145. Ramaswamy S, et al. Intrastriatal CERE120 (AAV-neurturin) protects striatal and cortical neurons and delays motor deficits in a transgenic mouse model of Huntington's disease. Neurobiol. Dis. 2009; 34:40-50. [PubMed: 19150499]

146. Arvanitakis $\mathrm{Z}$, et al. Interim data from a phase 1 clinical trial of AAV-NGF (CERE-110) gene delivery in Alzheimer's disease [abstract P05.071]. Neurology. 2007; 68(Suppl. 1):A233-A234.

147. Nagahara AH, et al. Neuroprotective effects of brain-derived neurotrophic factor in rodent andprimate models of Alzheimer's disease. Nat. Med. 2009; 3:331-337. [PubMed: 19198615]

148. Suzuki M, et al. GDNF secreting human neural progenitor cells protect dying motor neurons, but not their projection to muscle, in a rat model of familial ALS. PLoS ONE. 2007; 2:e689. [PubMed: 17668067]

149. Franz C, et al. Intraspinal cord delivery of IGF-I mediated by adeno-associated virus 2 is neuroprotective in a rat model of familial ALS. Neurobiol. Dis. 2009; 3:473-481. [PubMed: 19135533]

150. Kaspar BK, Llado J, Sherkat N, Rothstein JD, Gage FH. Retrograde viral delivery of IGF-1 prolongs survival in a mouse ALS model. Science. 2003; 5634:839-842. [PubMed: 12907804]

151. Smith RA, et al. Antisense oligonucleotide therapy for neurodegenerative disease. J. Clin. Invest. 2006; 8:2290-2296. [PubMed: 16878173]

152. Kanter-Schlifke I, Georgievska B, Kirik D, Kokaia M. Seizure suppression by GDNF gene therapy in animal models of epilepsy. Mol. Ther. 2007; 15:1106-1113. [PubMed: 17387333]

153. Theofilas $\mathrm{P}$, et al. Adenosine kinase as a target for therapeutic antisense strategies in epilepsy. Epilepsia. 2011; 52:589-601. [PubMed: 21275977]

154. Laing JM, et al. Intranasal administration of the growth-compromised HSV-2 vector $\Delta$ RR prevents kainate-induced seizures and neuronal loss in rats and mice. Mol. Ther. 2006; 13:870881. [PubMed: 16500153] 
155. Smitt PS, Driesse M, Wolbers J, Kros M, Avezaat C. Treatment of relapsed malignant glioma with an adenoviral vector containing the herpes simplex thymidine kinase gene followed by ganciclovir. Mol. Ther. 2003; 7:851-858. [PubMed: 12788659] 


\section{Key points}

- Standard pharmacological and surgical interventions are either inadequate or unavailable for most diseases of the PNS and CNS

- Gene therapy is a viable approach to the prevention of neurological disease progression, and might offer a cure or slow down the disease process

- The efficacy of gene therapy depends on the development of gene delivery vehicles (mostly viral vectors) to target disease-modifying products to where they are needed

- Gene therapy strategies to treat some diseases that affect vision and hearing or that cause debilitating pain are at an advanced stage of development

- Gene therapy for degenerative diseases requires a more in-depth understanding of the underlying pathophysiology and, for some diseases, global brain delivery of the transgene

- With ongoing development of gene therapy applications for nervous system disease, such treatments are expected to be available to patients within 10 years 


\section{Review criteria}

Review of the literature was conducted by searching the MEDLINE database using the following terms: "gene therapy", "genetic vectors", "retroviridae", "lentivirus", "adenoviridae", "dependovirus", "herpesviridae", "retina", "cochlea", "pain”, "brain diseases, metabolic, inborn", "lysosomal storage diseases", "neurodegenerative diseases", "Parkinson disease", "epilepsy" and "brain neoplasms", alone and in combination. Papers were selected on the basis of title, abstract or full version (when available). The reference sections of relevant articles were checked for additional relevant articles. 

Structural
Accessory
Replication and integration
Therapeutic
Essential
Deleted genes
or regulatory elements

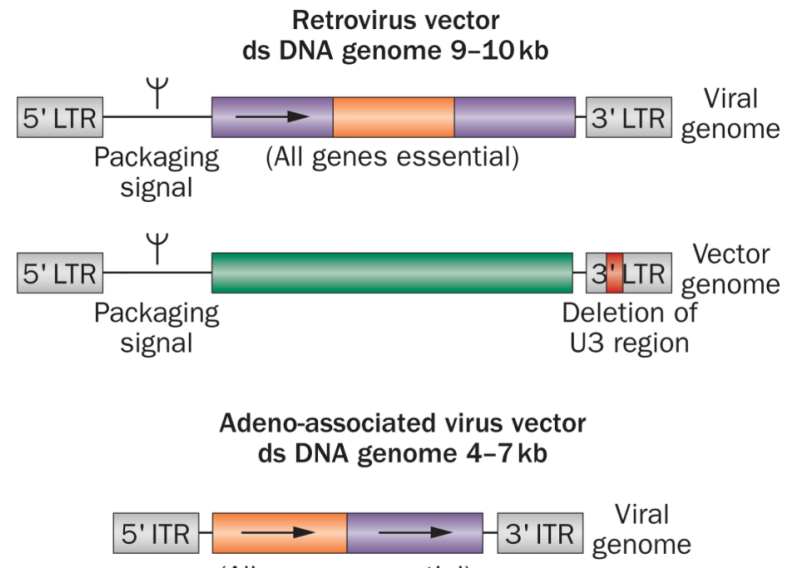

(All genes essential)
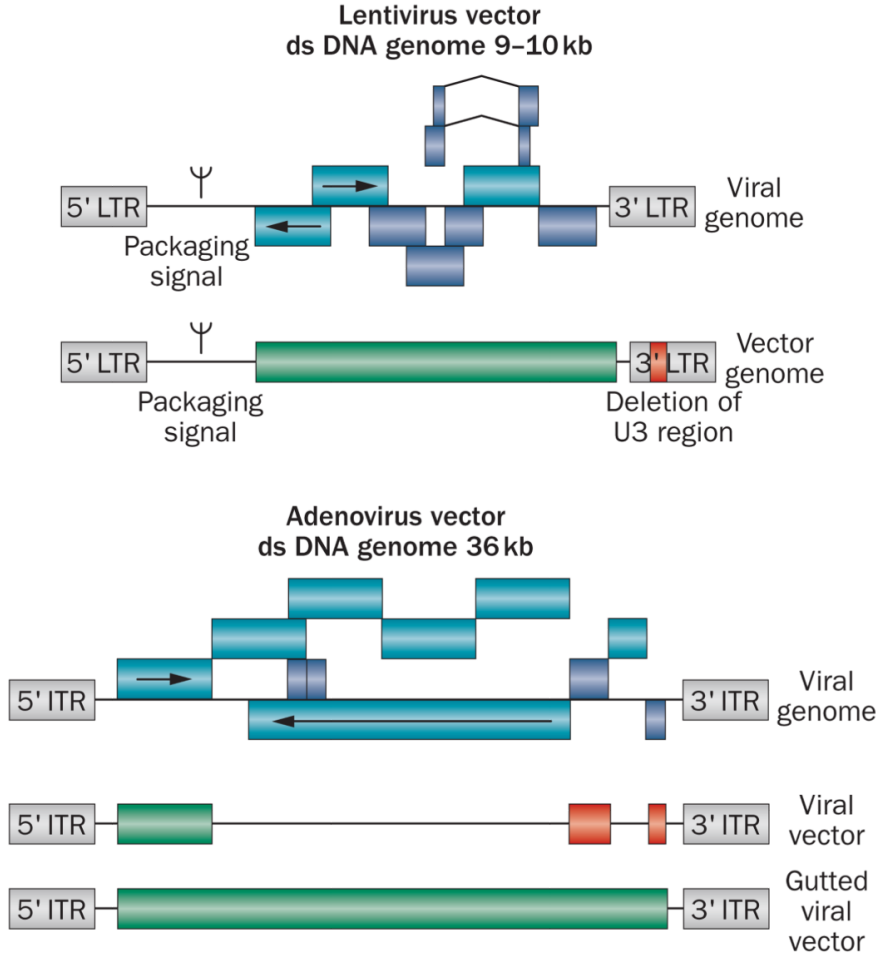

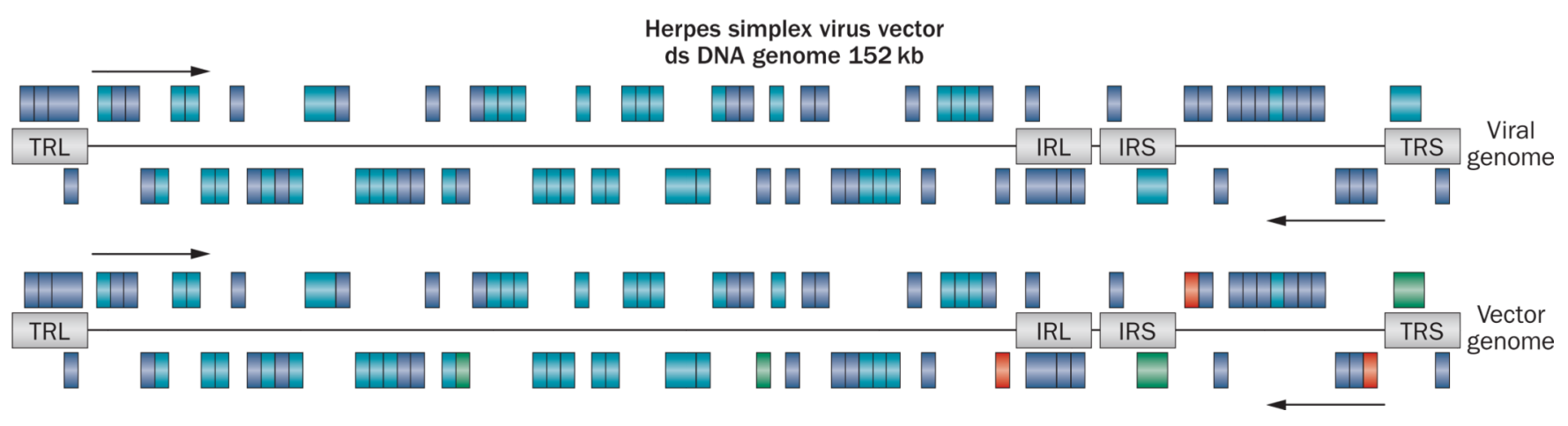

Figure 1.

Diagrams of the genomes of various viral vectors used in gene therapy approaches. Each diagram depicts the genome of the virus along with that of the corresponding viral vector, showing viral structural genes, viral genes involved in replication, and genes essential or non-essential (accessory) for virus replication or growth. Viral genes that are transcribed in the 5' to 3' direction (rightward arrow) are depicted above the viral genome, and those transcribed in the opposite direction (leftward arrow) are depicted below the genome. Genes or regulatory elements deleted from viral vectors are shown in red and common locations for introduction of the therapeutic gene in the vector genome are depicted in green.

Abbreviations: ds, double-stranded; ITR, inverted terminal repeat; IRL, inverted repeat long; IRS, inverted repeat short; LTR, long terminal repeat; TRS, terminal repeat short. 
a

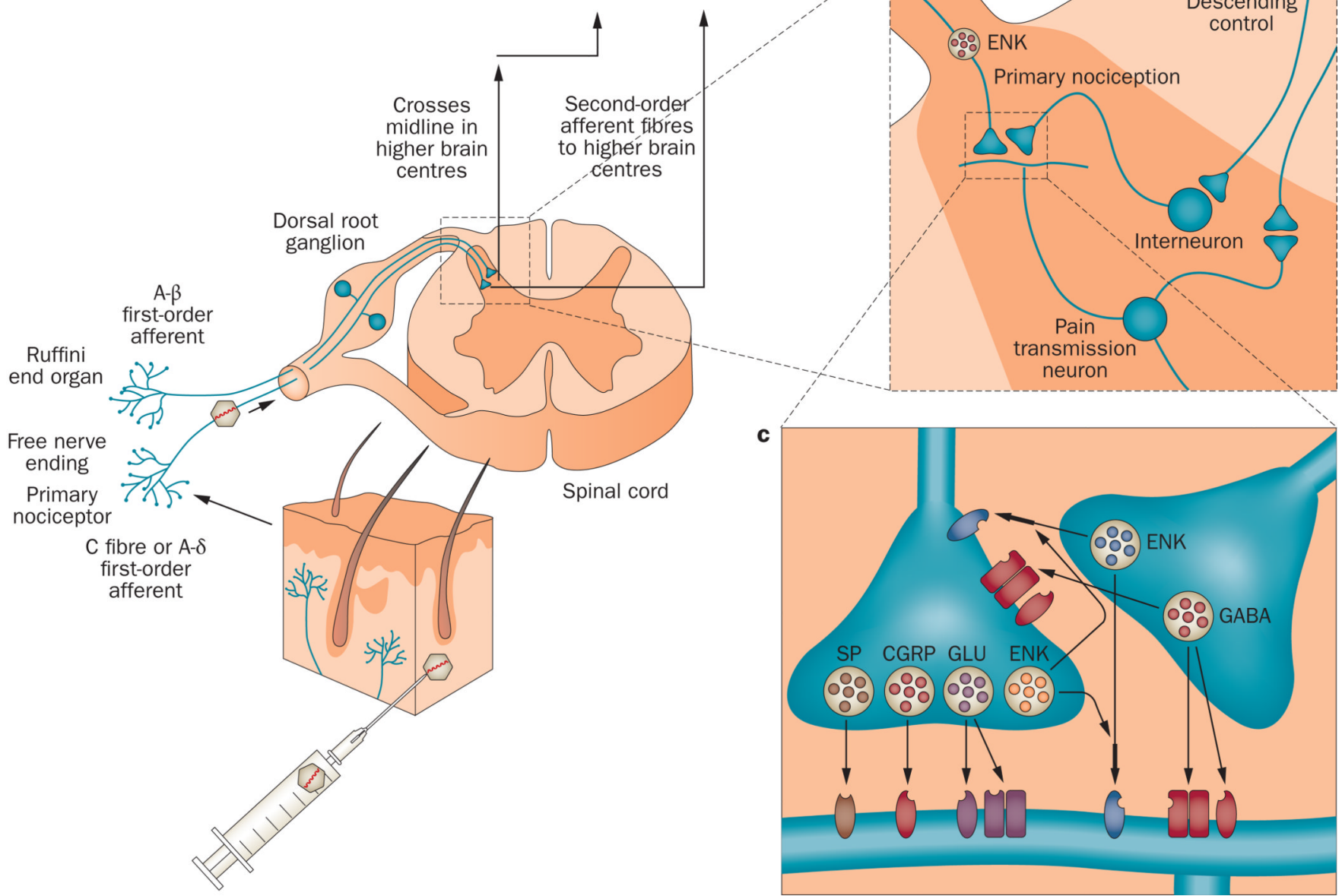

Figure 2.

Gene therapy for pain using an HSV vector. a,b | Pain signalling is mediated by primary sensory afferents that connect via synapses in the spinal cord to release neurotransmitters and peptides, including glutamate, substance $P$ and CGRP. After injection into the skin, the HSV vector is delivered to the cell bodies of primary afferents by retrograde axonal transport, enabling production and release of the transgene product (in this case ENK) from nerve terminals in the dorsal horn. $\mathbf{c} \mid$ ENK released from the transduced primary afferents inhibits nociceptive neurotransmission through binding to opioid receptors at presynaptic and postsynaptic sites Abbreviations: CGRP, calcitonin gene-related peptide; ENK, enkephalin; GAD, glutamic acid decarboxylase; GLU, glutamate; HSV, herpes simplex virus; $\mathrm{SP}$, substance $\mathrm{P}$. 


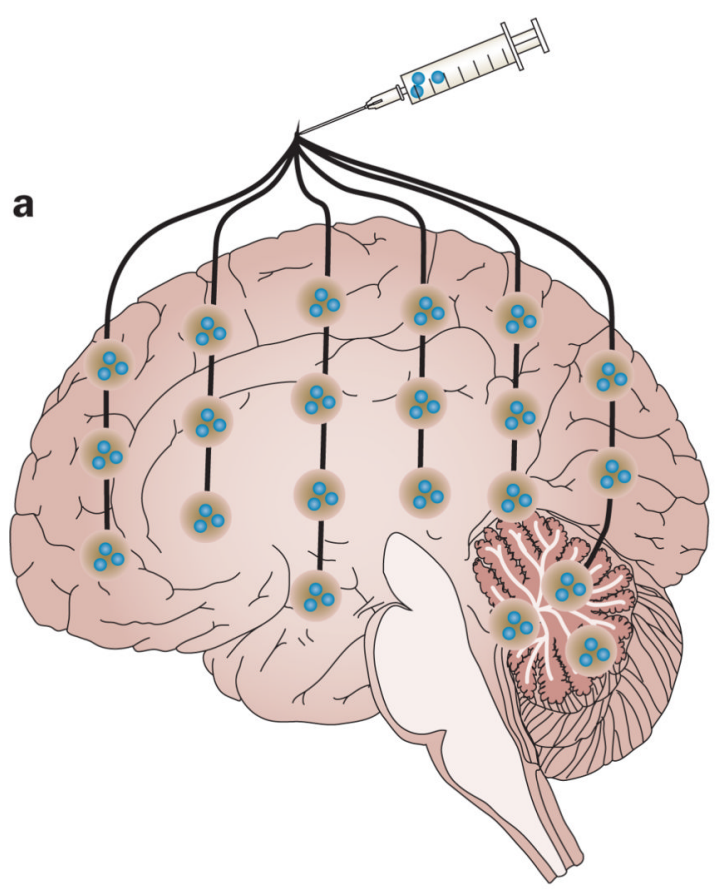

\section{b}
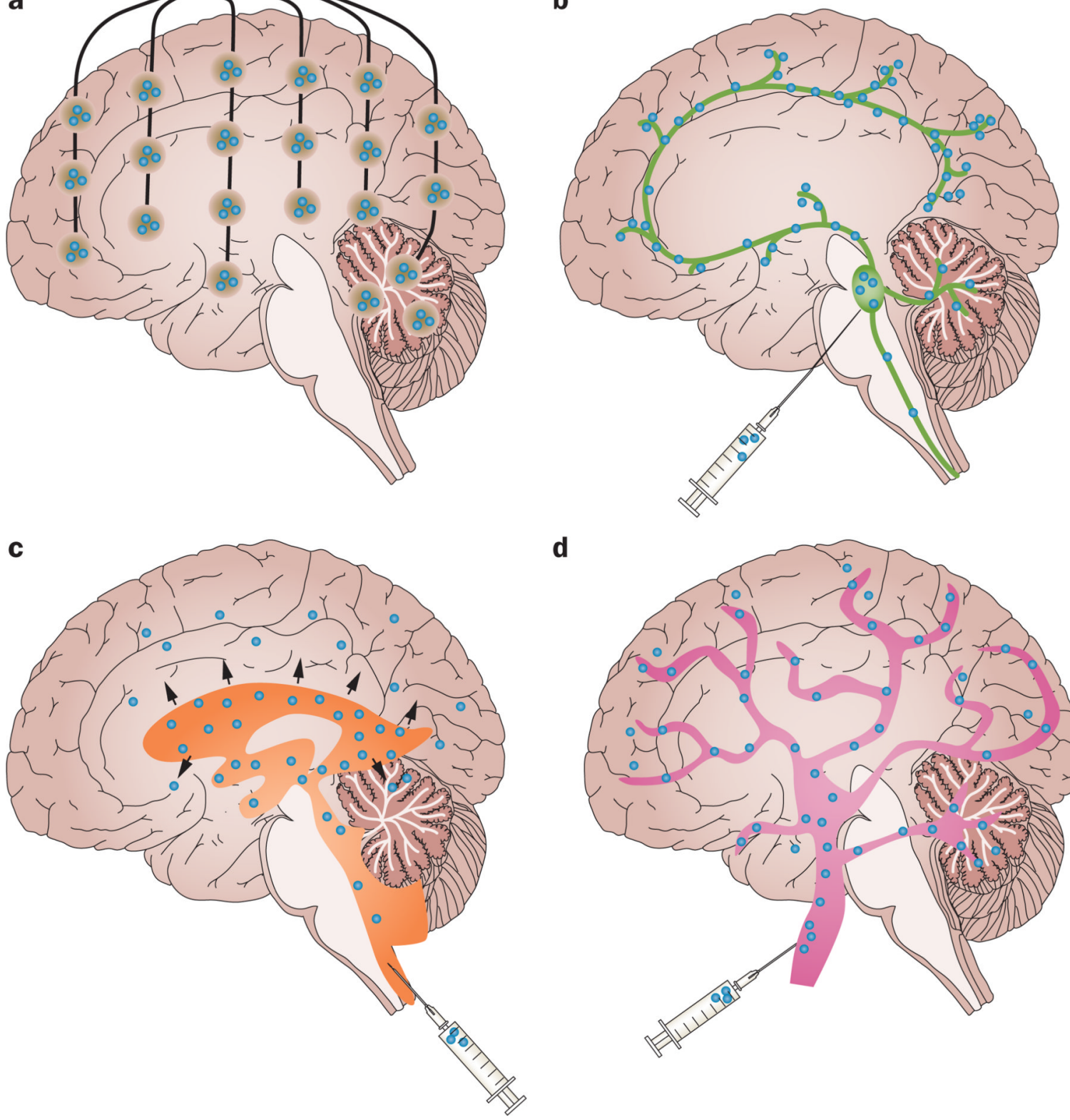

d

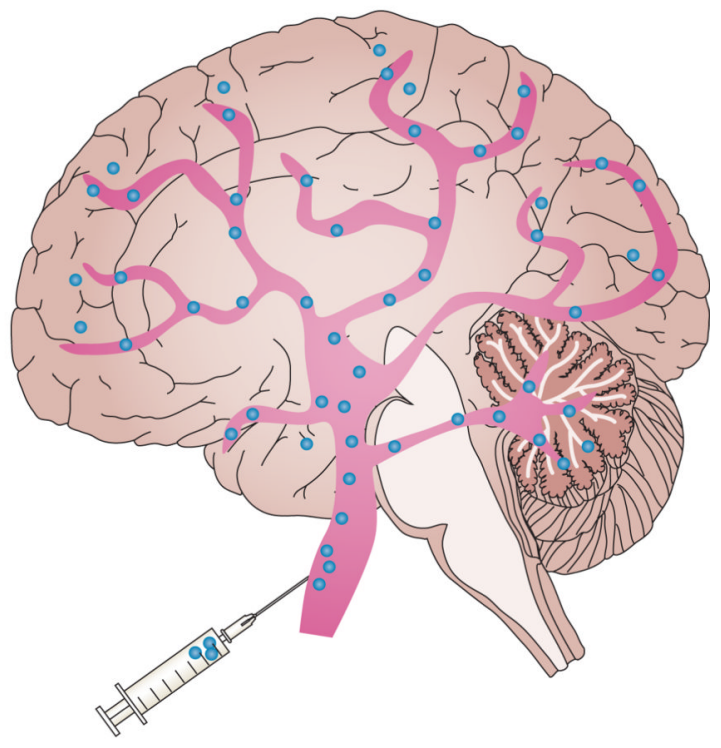

Figure 3.

Vector-delivery strategies for gene therapy of neurogenetic diseases. Most inherited neurological diseases have global brain pathology, which requires widespread distribution of the vector for effective treatment. Certain properties of a therapeutic gene product can enhance its therapeutic effect; for example, in diseases of lysosomal enzyme deficiency, a cell corrected by transduction with the vector can secrete the previously missing enzyme, which can then be endocytosed by neighbouring cells. Some proteins can also be transported via neural pathways within the brain, providing wide distribution. a| Multiple, distributed injection tracks into the brain parenchyma with multiple deposits of vector along each track. 
b | Vector transport via axonal pathways is dependent on the specific neural system and on vector design. c | Injection into the cerebrospinal fluid (ventricles, cisterna magna or spinal cord) produces variable patterns and amounts of vector distribution. $\mathbf{d}$ | Vector entry into the brain via administration of herpes simplex virus to the PNS, intravenous infusion of adenoassociated virus serotypes, transplantation of lentivirus-transduced haematopoietic stem cells, or temporary osmotic opening of the blood-brain barrier. 


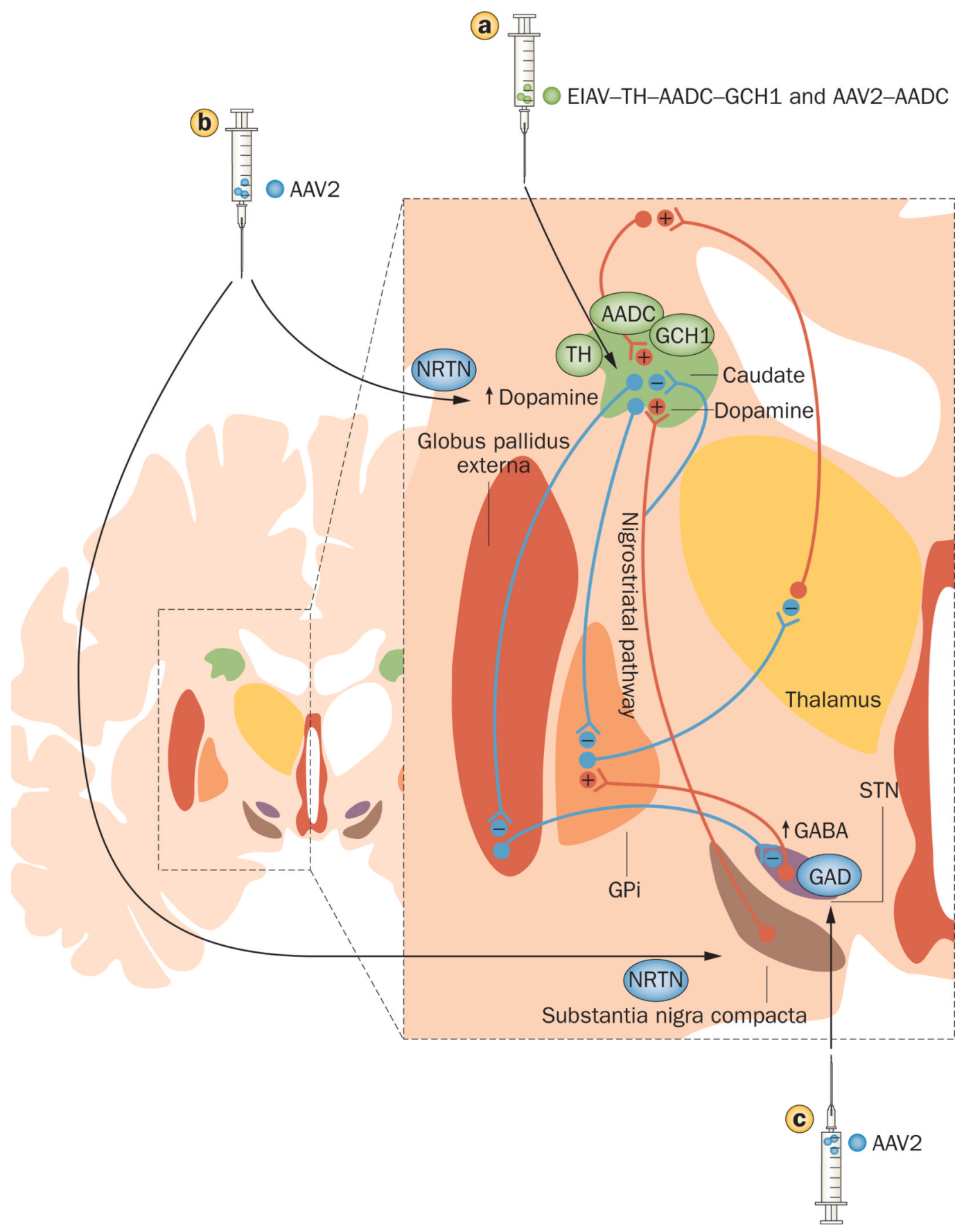

Figure 4.

Gene therapy targets in Parkinson disease. Excitatory connections from the cortex stimulate striatal neurons. Dopamine release regulates two populations of striatal neurons inversely: neurons that project directly to the GPi from the striatum are stimulated, and neurons that project to the GPi via the globus pallidus pars externa and STN are inhibited. Therefore, dopamine inhibits thalamic activity, which disinhibits the cortex and allows movement to occur. In PD, loss of dopaminergic neurons eliminates this cortical activation and inhibits movement. a | Vector injection into the caudate for the expression of dopamine producing enzymes replaces PD-related dopamine loss. b | Neurturin expression in the striatum and 
substantia nigra might preserve dopamine neurons, and enhance their function. $\mathbf{c} \mid$ Delivery of GAD to the STN induces GABA production, changing the STN input to the GPi from excitatory to inhibitory. GAD expression, therefore, reverses the abnormal increase in STN activity that occurs in PD, reducing the abnormally high GPi activity that prevents movement. Abbreviations: AADC, aromatic amino acid decarboxylase; GCH1, GTP cyclohydrolase 1; GABA, $\gamma$-aminobutyric acid; GAD, glutamic acid decarboxylase; GPi, globus pallidus pars interna; PD, Parkinson disease; STN, subthalamic nucleus; TH, tyrosine hydroxylase. 


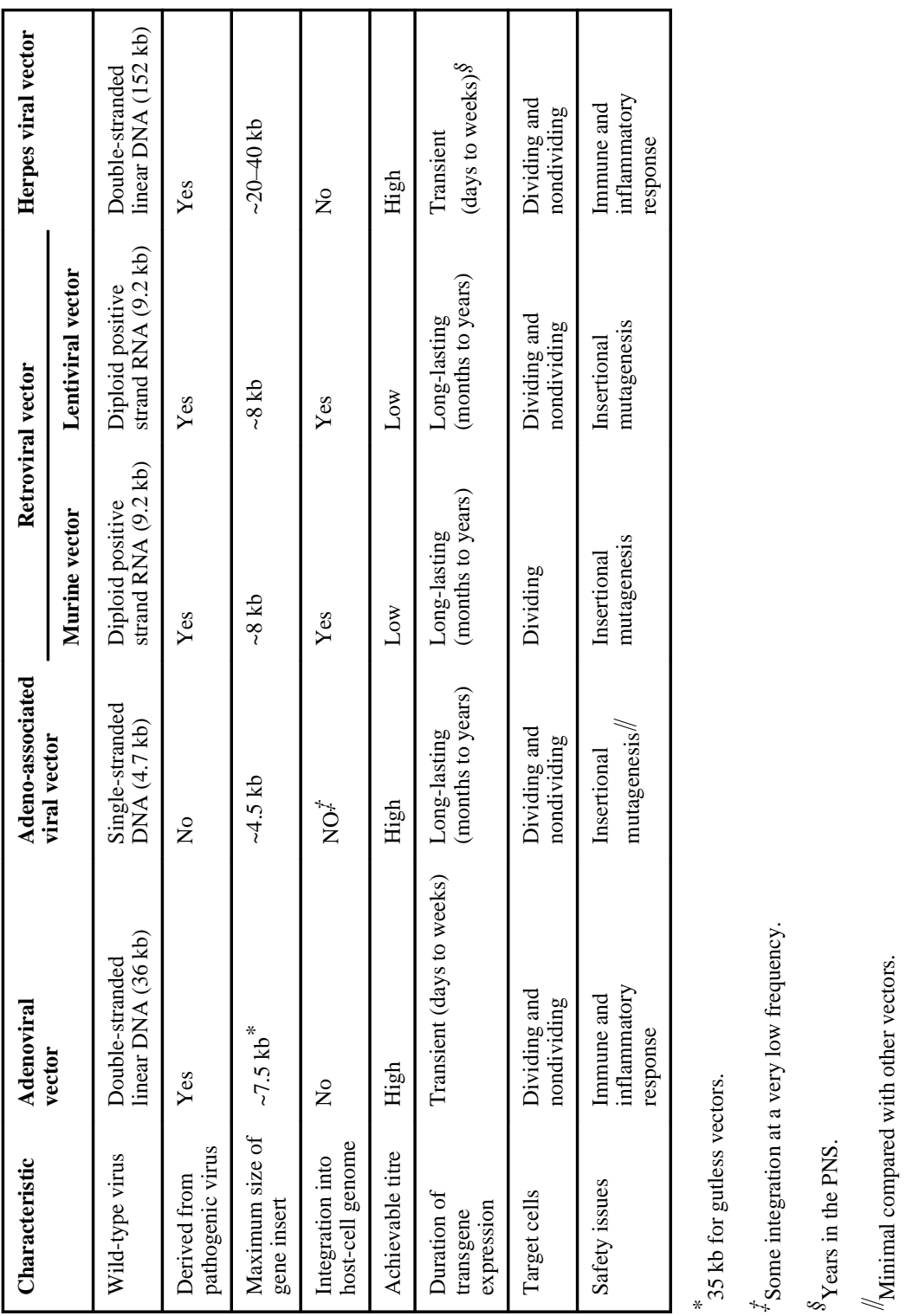


Table 2

Gene therapy for neurodegenerative diseases

\begin{tabular}{|c|c|c|c|c|}
\hline Study & Gene-delivery target & $\begin{array}{l}\text { Clinical trial } \\
\text { status }\end{array}$ & Viral vector & Therapeutic mechanism \\
\hline \multicolumn{5}{|l|}{ Parkinson disease } \\
\hline Christine et al. (2009) ${ }^{83}$ & $\begin{array}{l}\text { Stereotactic injection } \\
\text { into putamen }\end{array}$ & Phase I & AAV2 & $\begin{array}{l}A A D C \text { expression to convert } \\
\text { levodopa to dopamine }\end{array}$ \\
\hline $\begin{array}{l}\text { Jarraya et al. }(2009)^{80} \\
\text { Muramatsu et al. }(2010)^{75}\end{array}$ & $\begin{array}{l}\text { Stereotactic injection } \\
\text { into putamen }\end{array}$ & Phase I & $\begin{array}{l}\text { Equine infectious } \\
\text { anaemia virus }\end{array}$ & $\begin{array}{l}A A D C \text {-mediated expression of } \\
\text { tyrosine hydroxylase } \\
\text { and GTP cyclohydrolase } 1 \text { to } \\
\text { stimulate autonomous } \\
\text { dopamine production from tyrosine }\end{array}$ \\
\hline Marks et al. $(2010)^{92}$ & $\begin{array}{l}\text { Stereotactic injection } \\
\text { into putamen }\end{array}$ & Phase II & AAV2 & $\begin{array}{l}\text { NRTN expression protects } \\
\text { substantia nigra neurons, } \\
\text { and promotes nigrostriatal } \\
\text { regeneration and } \\
\text { upregulation of dopamine } \\
\text { production }\end{array}$ \\
\hline Kells et al. $(2010)^{142}$ & $\begin{array}{l}\text { Stereotactic injection } \\
\text { into putamen }\end{array}$ & Phase I-II & AAV2 & $G D N F$ expression similar to $N R T N$ \\
\hline Bartus et al. (in press) ${ }^{143}$ & $\begin{array}{l}\text { Stereotactic injection into } \\
\text { substantia nigra and } \\
\text { putamen }\end{array}$ & Phase II & AAV2 & $N R T N$ expression \\
\hline Lewitt et al. $(2011)^{88}$ & $\begin{array}{l}\text { Stereotactic injection into } \\
\text { subthalamic nucleus }\end{array}$ & Phase II & AAV2 & $\begin{array}{l}\text { Glutamic acid decarboxylase gene } \\
\text { expression converts } \\
\text { glutamate to } \gamma \text {-aminobutyric acid, } \\
\text { thereby increasing } \\
\text { synaptic inhibition in the } \\
\text { subthalamic nucleus }\end{array}$ \\
\hline \multicolumn{5}{|l|}{ Huntington disease } \\
\hline McBride et al. (2011) $)^{144}$ & $\begin{array}{l}\text { Stereotactic injection } \\
\text { into striatum }\end{array}$ & Preclinical & AAV2 & $\begin{array}{l}N R T N \text { expression provides } \\
\text { neuroprotection }\end{array}$ \\
\hline $\begin{array}{l}\text { Ramaswamy et al } \\
(2009)^{145}\end{array}$ & $\begin{array}{l}\text { Injection of striatum or } \\
\text { diffuse } \\
\text { delivery (intravenous) }\end{array}$ & Preclinical & AAV & $\begin{array}{l}\text { Expression of mutant Huntingtin } \\
\text { siRNA (allele specific) }\end{array}$ \\
\hline \multicolumn{5}{|l|}{ Alzheimer disease } \\
\hline $\begin{array}{l}\text { Aravanitakis et al } \\
(2007)^{146}\end{array}$ & $\begin{array}{l}\text { Stereotactic injection } \\
\text { into nucleus of Meynert }\end{array}$ & Phase II & AAV2 & $\begin{array}{l}\text { Nerve growth factor gene } \\
\text { expression enhances } \\
\text { cholinergic neuron protection, } \\
\text { axonal regeneration } \\
\text { and upregulation of acetylcholine } \\
\text { production }\end{array}$ \\
\hline Nagahara et al. (2009) ${ }^{147}$ & $\begin{array}{l}\text { Stereotactic injection } \\
\text { into entorhinal cortex }\end{array}$ & Preclinical & AAV2 & $\begin{array}{l}\text { Expression of brain-derived } \\
\text { neurotrophic factor } \\
\text { enhances neuroprotection and } \\
\text { axonal regeneration }\end{array}$ \\
\hline \multicolumn{5}{|l|}{ Amyotrophic lateral sclerosis } \\
\hline Suzuki et al. $(2007)^{148}$ & Injection into spinal cord & Preclinical & $\begin{array}{l}\text { Lentivirus- } \\
\text { transduced neural } \\
\text { progenitors }\end{array}$ & $\begin{array}{l}\text { Ex vivo gene transfer of } G D N F \text { to } \\
\text { human neural } \\
\text { progenitor cells }\end{array}$ \\
\hline Franz et al. $(2009)^{149}$ & Ventral horn of spinal cord & Preclinical & AAV2 & $I G F 1$ expression \\
\hline $\begin{array}{l}\text { Boulis (personal communication; } \\
\text { trial not yet initiated) }\end{array}$ & $\begin{array}{l}\text { Remote gene delivery; } \\
\text { intravenous or intrathecal }\end{array}$ & Preclinical & AAV9 & $\begin{array}{l}I G F 1 \text { or } G D N F \text { as candidate } \\
\text { transgenes }\end{array}$ \\
\hline Kaspar et al. $(2003)^{150}$ & $\begin{array}{l}\text { Remote gene delivery by } \\
\text { retrograde axonal } \\
\text { transport; }\end{array}$ & Preclinical & AAV2 & $I G F 1$ or $G D N F$ \\
\hline
\end{tabular}




\begin{tabular}{|c|c|c|c|c|}
\hline Study & Gene-delivery target & $\begin{array}{l}\text { Clinical trial } \\
\text { status }\end{array}$ & Viral vector & Therapeutic mechanism \\
\hline & nerve or muscle injection & & & Expression of mutant SOD1 siRNA \\
\hline Smith et al. (2006) $)^{151}$ & Intrathecal injection & Phase I & $\begin{array}{l}\text { Naked nucleic } \\
\text { acid }\end{array}$ & $\begin{array}{l}\text { Delivery of antisense } \\
\text { oligonucleotides to target } \\
\text { mutated SOD1 }\end{array}$ \\
\hline
\end{tabular}

Abbreviations: $A A D C$, aromatic amino acid decarboxylase; AAV, adeno-associated virus; GDNF, glial cell line-derived neurotrophic factor; IGF1, insulin-like growth factor 1; NRTN, neurturin; siRNA, small interfering RNA; SOD1, superoxide dismutase 1. 
Table 3

Gene therapy for epilepsy

\begin{tabular}{|c|c|c|c|c|}
\hline $\begin{array}{l}\text { Protein encoded by } \\
\text { transgene }\end{array}$ & Vector & Time of treatment & Effects & References \\
\hline $\begin{array}{l}\text { Fibroblast growth } \\
\text { factor } 2 \text { and } \\
\text { brain-derived } \\
\text { neurotrophic factor }\end{array}$ & HSV-1 & $\begin{array}{l}\text { Latency ( } 4 \text { days after } \\
\text { epileptogenic } \\
\text { insult [pilocarpine]) }\end{array}$ & $\begin{array}{l}\text { Antiepileptogenic: reduced } \\
\text { seizure frequency } \\
\text { and severity } \\
\text { Disease-modifying: attenuated } \\
\text { epileptogenesis- } \\
\text { associated pathology; reduced } \\
\text { cell loss, } \\
\text { neuroinfammation and mossy } \\
\text { fibre sprouting; } \\
\text { increased neurogenesis }\end{array}$ & $\begin{array}{l}\text { Paradiso et al. }(2009)^{97} \\
\text { Bovolenta et al. }(2010)^{98} \\
\text { Paradiso et al. }(2011)^{99}\end{array}$ \\
\hline $\begin{array}{l}\gamma \text {-aminobutyric acid } \\
\text { receptor A subunit a1 }\end{array}$ & AAV2 & $\begin{array}{l}\text { Before epileptogenic insult } \\
\text { (pilocarpine) }\end{array}$ & $\begin{array}{l}\text { Antiseizure: decreased } \\
\text { percentage of animals } \\
\text { with spontaneous seizures }\end{array}$ & Raol et al. $(2006)^{101}$ \\
\hline $\begin{array}{l}N \text {-methyl-D-aspartate } \\
\text { subunit NR1 }{ }^{*}\end{array}$ & AAV2 & $\begin{array}{l}\text { Before inferior collicus } \\
\text { stimulation }\end{array}$ & $\begin{array}{l}\text { Antiseizure or proseizure, } \\
\text { depending on promoter } \\
\text { used and transduced cell type }\end{array}$ & $\begin{array}{l}\text { Haberman et al. } \\
(2002)^{100}\end{array}$ \\
\hline Galanin & AAV2 & $\begin{array}{l}\text { Before epileptogenic insult } \\
\text { (kainate) } \\
\text { Epileptic animals (fully } \\
\text { kindled) }\end{array}$ & $\begin{array}{l}\text { Antiseizure: increased seizure } \\
\text { threshold, reduced } \\
\text { seizure frequency and severity, } \\
\text { reduced number } \\
\text { of animals experiencing } \\
\text { seizures } \\
\text { Disease-modifying: reduced } \\
\text { cell loss }\end{array}$ & $\begin{array}{l}\text { Haberman et al. } \\
(2003)^{103} \\
\text { Lin } \text { et al. }(2003)^{104} \\
\text { McCown } \text { et al. }(2006)^{106}\end{array}$ \\
\hline NPY & Chimaeric AAV1/2 & $\begin{array}{l}\text { Before epileptogenic insult } \\
\text { (kainate or kindling) } \\
\text { In chronic period (with } \\
\text { spontaneous seizures) } \\
\text { after epileptogenic insult } \\
\text { (self-sustained status } \\
\text { epilepticus) }\end{array}$ & $\begin{array}{l}\text { Antiseizure: increased latency } \\
\text { to seizure, reduced } \\
\text { seizure frequency and duration, } \\
\text { and slowed } \\
\text { kindling development } \\
\text { Disease-modifying: arrested } \\
\text { disease progression } \\
\text { No adverse reactions: no } \\
\text { alterations in learning } \\
\text { and memory, anxiety or } \\
\text { locomotor activity }\end{array}$ & $\begin{array}{l}\text { Richichi et al. }(2004)^{105} \\
\text { Foti } \text { et al. }(2007)^{107} \\
\text { Noe } \text { et al. }(2008)^{108} \\
\text { Sorensen } \text { et al. }(2009)^{109} \\
\text { Noe et al. }(2010)^{110}\end{array}$ \\
\hline NPY and NPY2R & $\begin{array}{l}\text { Chimaeric } \\
\text { AAV1/2 }\end{array}$ & $\begin{array}{l}\text { Before epileptogenic insult } \\
\text { (kindling) }\end{array}$ & $\begin{array}{l}\text { Antiseizure effects more potent } \\
\text { than with NPY alone }\end{array}$ & Woldbye et al. $(2010)^{111}$ \\
\hline $\begin{array}{l}\text { Glial cell line-derived } \\
\text { neurotrophic factor }\end{array}$ & AAV2 & $\begin{array}{l}\text { Before epileptogenic insult } \\
\text { (kindling, self-sustained status } \\
\text { epilepticus) }\end{array}$ & $\begin{array}{l}\text { Antiseizure: increased seizure } \\
\text { threshold, prevented } \\
\text { seizure generalization, reduced } \\
\text { seizure severity } \\
\text { and mortality }\end{array}$ & $\begin{array}{l}\text { Kanter-Schlifke et al } \\
(2007)^{152}\end{array}$ \\
\hline Adenosine kinase ${ }^{*}$ & AAV8 & $\begin{array}{l}\text { Epileptic animals } \\
\text { (spontaneously seizing } \\
\text { adenosine kinase transgenic } \\
\text { mice) }\end{array}$ & $\begin{array}{l}\text { Antiseizure: reduced frequency } \\
\text { of spontaneous seizures }\end{array}$ & Theofilas et al. (2011) ${ }^{153}$ \\
\hline $\begin{array}{l}\text { ICP10PK } \\
\text { (antiapoptotic protein) }\end{array}$ & HSV-2 & $\begin{array}{l}\text { Before epileptogenic insult } \\
\text { (kainate) }\end{array}$ & $\begin{array}{l}\text { Antiseizure:prevented seizures } \\
\text { Disease-modifying: prevented } \\
\text { neuronal loss } \\
\text { and inflammation }\end{array}$ & Laing et al. (2006) $)^{154}$ \\
\hline $\begin{array}{l}\text { Voltage-gated } \\
\text { potassium channel } \\
\text { subunit Kv1.1 }\end{array}$ & Lentivirus & $\begin{array}{l}\text { During or after epileptogenic } \\
\text { insult } \\
\text { (tetanus toxin in motor cortex) }\end{array}$ & $\begin{array}{l}\text { Antiepileptogenic: prevented } \\
\text { epileptiform events } \\
\text { after administration during } \\
\text { epileptogenic insult } \\
\text { Disease-modifying: reduced } \\
\text { frequency of epileptiform } \\
\text { events following } \\
\text { administration in established } \\
\text { epilepsy }\end{array}$ & Wykes et al. $(2012)^{102}$ \\
\hline
\end{tabular}


* Antisense DNA.

Abbreviations: AAV, adeno-associated virus; HSV, herpes simplex virus; NPY, neuropeptide Y; NPY2R, NPY2 receptor. 


\begin{tabular}{|c|c|c|c|c|c|c|c|c|c|c|c|c|c|c|c|}
\hline 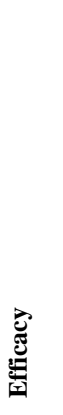 & 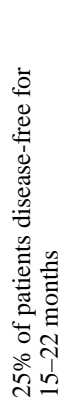 & 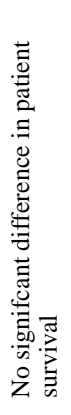 & 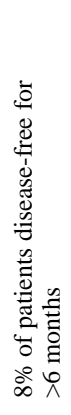 & 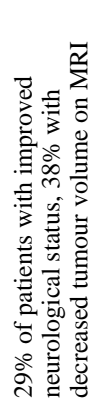 & 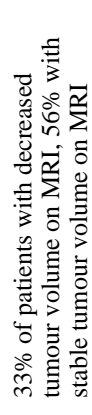 & 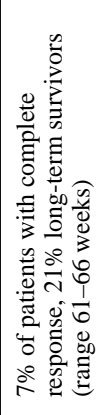 & 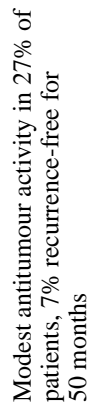 & 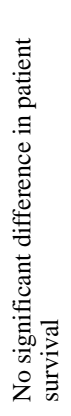 & 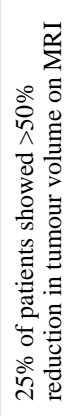 & 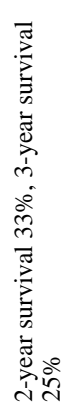 & 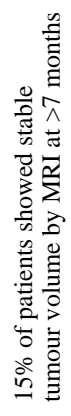 & 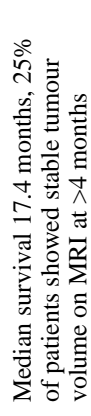 & 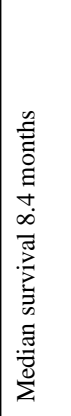 & 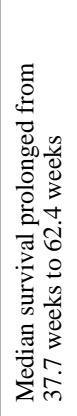 & 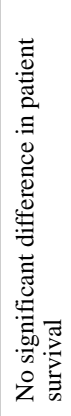 \\
\hline 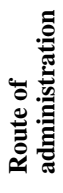 & 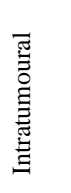 & 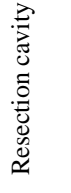 & 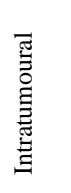 & 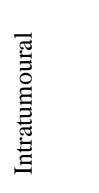 & 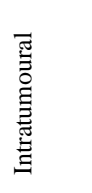 & 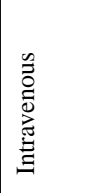 & 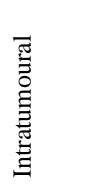 & 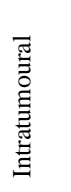 & 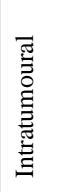 & 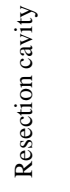 & 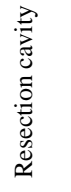 & 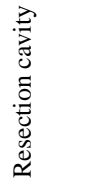 & 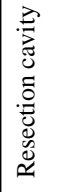 & 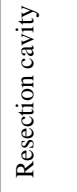 & 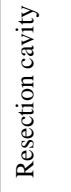 \\
\hline 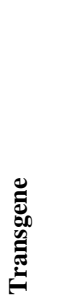 & 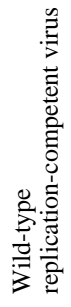 & 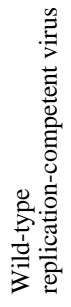 & 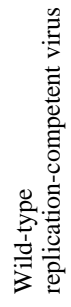 & 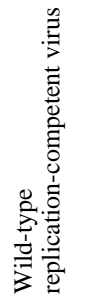 & 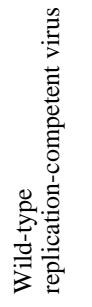 & 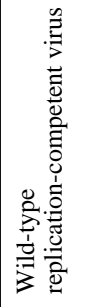 & 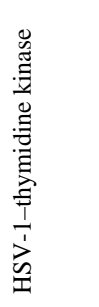 & 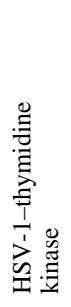 & 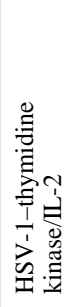 & 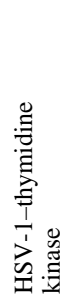 & 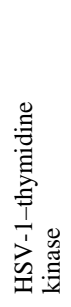 & 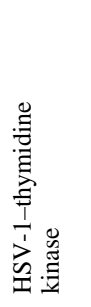 & 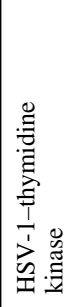 & 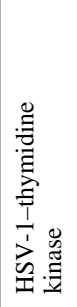 & 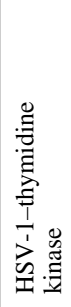 \\
\hline 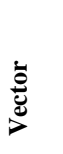 & 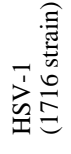 & 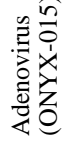 & 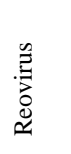 & 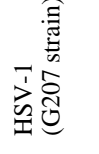 & 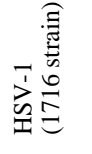 & 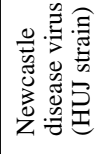 & 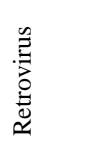 & 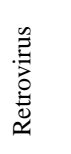 & 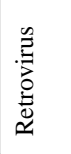 & 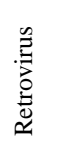 & 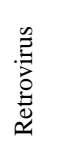 & 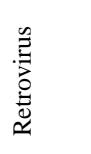 & 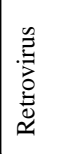 & 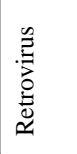 & 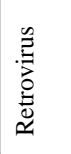 \\
\hline 密部 & 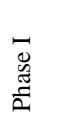 & $\begin{array}{l}\vec{D} \\
\overline{\mathscr{J}} \\
\overline{\tilde{D}}\end{array}$ & $\begin{array}{l}\bar{D} \\
\bar{E} \\
\mathbb{E}\end{array}$ & $\begin{array}{l}\mathscr{\mathscr { E }} \\
\frac{\mathscr{\Xi}}{\tilde{N}}\end{array}$ & $\begin{array}{l}\mathscr{\mathscr { E }} \\
\frac{\pi}{2}\end{array}$ & 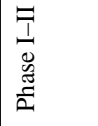 & $\begin{array}{l}\bar{D} \\
\tilde{z} \\
\frac{\pi}{2}\end{array}$ & $\begin{array}{l}\mathscr{\mathscr { m }} \\
\frac{\tilde{\Xi}}{2}\end{array}$ & 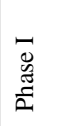 & $\begin{array}{l}\Rightarrow \\
\ddot{0} \\
\ddot{\Xi} \\
\frac{\pi}{2}\end{array}$ & 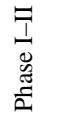 & 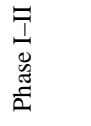 & 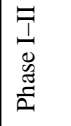 & 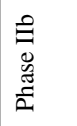 & 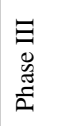 \\
\hline 密 & 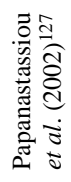 & 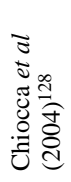 & 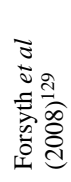 & 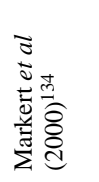 & 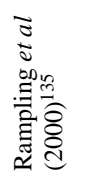 & 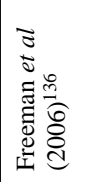 & 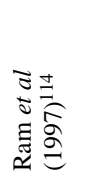 & 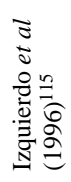 & 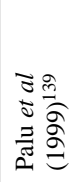 & 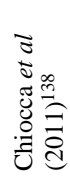 & 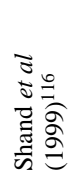 & 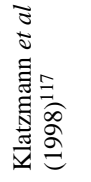 & 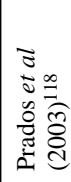 & 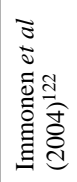 & $\begin{array}{l}\text { 总 } \\
\text { 言 } \\
\text { 乞 }\end{array}$ \\
\hline
\end{tabular}

Nat Rev Neurol. Author manuscript; available in PMC 2014 January 31. 


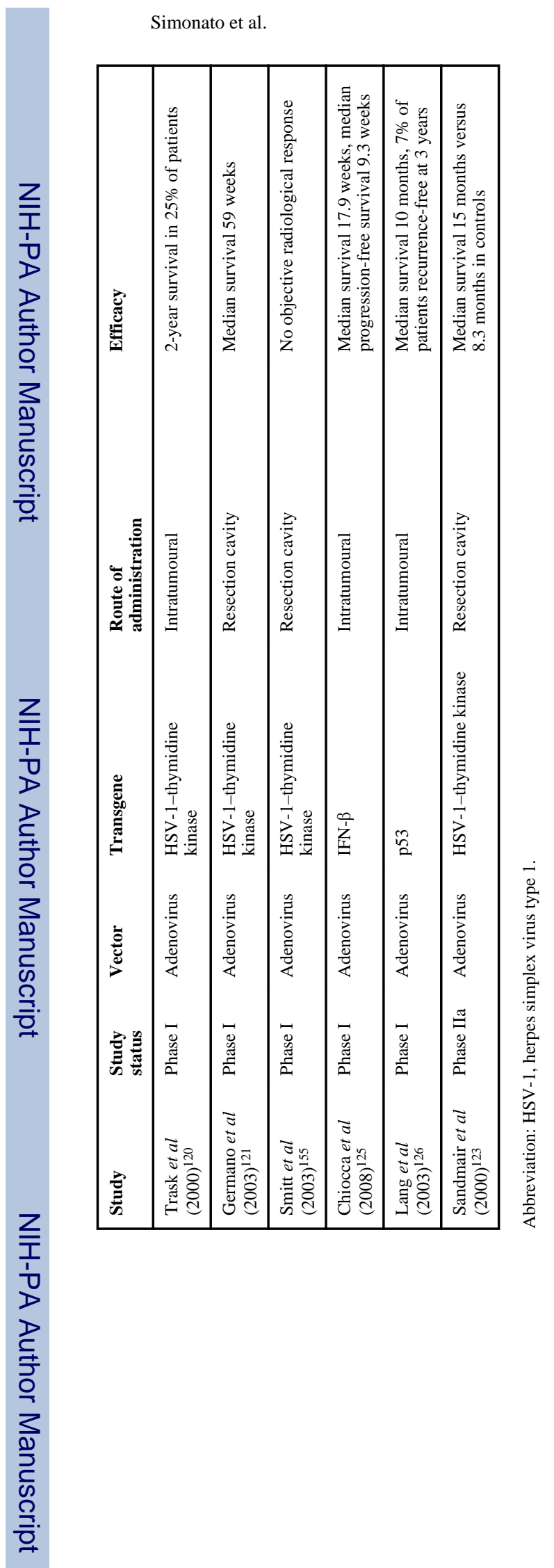

Nat Rev Neurol. Author manuscript; available in PMC 2014 January 31. 